Provided for non-commercial research and education use. Not for reproduction, distribution or commercial use.

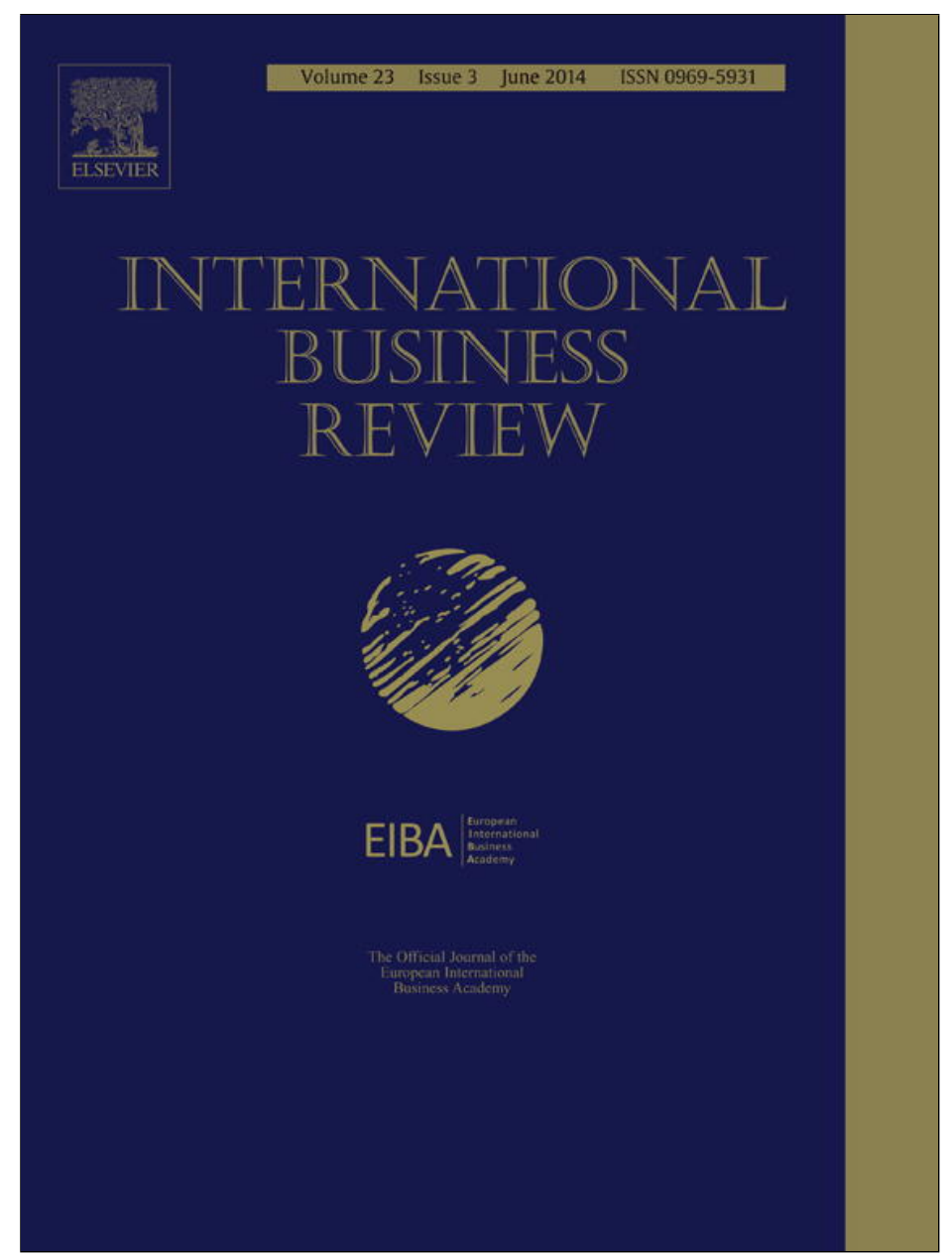

This article appeared in a journal published by Elsevier. The attached copy is furnished to the author for internal non-commercial research and education use, including for instruction at the authors institution and sharing with colleagues.

Other uses, including reproduction and distribution, or selling or licensing copies, or posting to personal, institutional or third party websites are prohibited.

In most cases authors are permitted to post their version of the article (e.g. in Word or Tex form) to their personal website or institutional repository. Authors requiring further information regarding Elsevier's archiving and manuscript policies are encouraged to visit:

http://www.elsevier.com/authorsrights 


\title{
Spillovers through backward linkages and the export performance of business services. Evidence from a sample of Italian firms
}

\author{
Giuliano Conti ${ }^{1}$, Alessia Lo Turco ${ }^{2}$, Daniela Maggioni* \\ Università Politecnica delle Marche, Department of Economics and Social Sciences, Piazzale Martelli 8, 60121 Ancona, Italy
}

\section{A R T I C L E I N F O}

\section{Article history:}

Received 30 June 2012

Received in revised form 6 September 2013

Accepted 23 September 2013

Available online 17 October 2013

\section{Keywords:}

Backward linkages

Business services

Firms' internationalisation

\begin{abstract}
A B S T R A C T
We provide evidence on the role of spillovers through vertical linkages in service firms internationalisation process. We combine input-output coefficients with region-level information on downstream manufacturing sector exports to build a measure of spillovers through backward linkages, which we assess as a systematic determinant of Italian BS firms' export status. Once considered firm and sector specificities, export spillovers especially matter for exporting to high-income economies outside Europe. This finding originates from higher sunk costs stemming from greater distance to the destination market and tougher competition within the destination market. Furthermore, the spillovers' geographical scope is mainly local. We thus contribute to international business theory by generalising existing evidence from case studies on the importance of buyer-supplier relationships for service firms' internationalisation across several BS sectors. Our research carries important implications for international business practices as well, as joining networks with internationalised customers may play an important role in enhancing BS firms' exports, regardless of the BS supplied.
\end{abstract}

๑) 2013 Elsevier Ltd. All rights reserved.

\section{Introduction}

In recent decades, employment and production have moved from manufacturing to services, which today represent the majority of high-income countries' GDP. Rapid developments of Information and Communication Technology (ICT) and growing global integration have stimulated trade in services - traditionally considered non-tradable - and today more and more services firms face the same international competition pressure as manufacturing firms. Literature has shown that export specialisation plays a relevant role in long-run growth and welfare (Hausmann, Hwang, \& Rodrik, 2007; Lucas, 1988), and exporting high-skill-intensive services may become fundamental for the future of advanced countries. It is then crucial to shed light on the determinants of the business services (BS) firms' export propensity in order to gather some insights about countries' economic perspectives.

In this study, we therefore focus on the determinants of services firms' exports and, specifically, we test whether vertical linkages between manufacturing exporters and upstream BS providers act as a channel for the transmission of positive export spillovers which facilitate BS firms' export activity.

\footnotetext{
* Corresponding author. Tel.: +39 071220 7239; fax: +39 0712207102 .

E-mail addresses: g.conti@univpm.it (G. Conti), a.loturco@univpm.it (A. Lo Turco),d.maggioni@univpm.it (D. Maggioni).

1 Deceased.

2 Tel.: +390712207250
}

Motivated by interactivity, intangibility and inseparability between production and consumption which characterise a large part of services (Blomstermo \& Sharma, 2003) and by the upsurge of BS Foreign Direct Investments (FDI) in the last decades (UNCTAD, 2008, 2012), the most recent existing literature has mainly focused on BS trade occurring via the WTO-GATS mode 3 , that is via the firm's direct commercial presence with own subsidiaries in foreign markets. As the latter represents the predominant entry mode in services (Lejour \& Smith, 2008), literature has then investigated BS firms' penetration of foreign markets in terms of commitment and control (Pla-Barber, SanchezPeinado, \& Madhok, 2010; Villar, Pla-Barber, \& León-Darder, 2012) and, within the general analysis of the international expansion of BS multinationals, a stream of research has started investigating their subsidiaries' linkages with local firms (Miozzo \& Grimshaw, 2008; Miozzo, Yamin, \& Ghauri, 2012). ${ }^{3}$ Nevertheless, as Information and Communication Technologies advance and spread, it is rather likely that many services firms sell their product abroad with the involvement of limited resources. Therefore, less resource-intensive internationalisation modes are viable in the

\footnotetext{
${ }^{3}$ In particular, Miozzo and Grimshaw (2008) explore IT service multinationals' forward linkages with client firms in middle income economies and find that clients' absorptive capacity is important in securing positive forward linkages. Also being in a business relationship with an IT service multinational helps clients to become more footloose and less dependent on and connected to the local economy. Miozzo et al. (2012) instead explore the extent of backward linkages and show that the latter is limited as service multinationals tend to prefer global suppliers.
} 
form of services "embodied" in objects, in people and domestically located exports (Ball et al., 2008). The latter modes correspond to the WTO-GATS services exports modes 1, 2 and 4 which identify those of services exports that actually enter the balance of payment definition of cross-border trade in services. The systematic analysis of the determinants of this type of exports has been rather neglected. Only recently has the improved availability of larger samples of services firms allowed for more systematic empirical work on the importance of firm-level services exports determinants - for instance, firm size, productivity, and innovation activity - (Love \& Mansury, 2009, for the U.S.A.; Gourlay, Seaton, \& Suppakitjarak, 2005, for the U.K.; Eickelpasch \& Vogel, 2009, for Germany) and for a comparison with findings for manufacturing firms (Jaklič, Ćirjaković, \& Chidlow, 2012; Javalgi, Lawson, Gross, \& White, 1998). ${ }^{4}$ However, despite the centrality of the network perspective highlighted by the services firm internationalisation theory, existing evidence lacks any systematic treatment of the relevance of the relationship with customers in the manufacturing sector for services firms' export activity.

With this paper we thus aim at contributing to fill this gap and we address the following main research question: is upstream BS providers' export activity systematically favoured by spillovers accruing through vertical linkages with downstream manufacturing exporting firms?

Our work is then grounded on the network perspective of the firm internationalisation process (Johanson \& Mattsson, 1988) and is motivated by case studies' evidence showing that the success of services firms in exporting is strictly related to the economic environment in which they operate and, especially, to information externalities spurring from their relationship with customers (Bell, 1995; Coviello \& Munro, 1997). Although case studies yield much information and describe in detail the firm internationalisation experience, evidence based on large firm-level samples is fundamental to understand the systematic export propensity determinants for services firms and thus generalising and extending across firms and services activities the insights suggested by single cases (Javalgi et al., 1998).

Despite the fact that vertical interdependence between buyers and suppliers is not specific to service provision (Martin, Swaminathan, \& Mitchell, 1998) and vertical backward linkages in general constitute an important channel through which spillovers occur (Giroud, 2012; Javorcik, 2004), ${ }^{5}$ services firms, compared to manufacturing ones, face higher export entry costs and could particularly benefit from spillovers through vertical linkages. The export experience of customers based in the manufacturing sector could therefore ease services firms' access to the export market through different channels. Internationalised customers may provide strong testimonials abroad, they may represent an informal bridge to set up relationships with new foreign customers and they may transfer precious information necessary for the adaptation of services to the foreign markets.

In order to assess the significance and importance of such spillovers through backward linkages we estimate a probit model for the export status of Italian services firms by making use of the 2001-2003 CAPITALIA survey. From the survey design we are able to exactly identify cross-border exporters. Our sample covers

\footnotetext{
${ }^{4}$ Buckley, Pass, and Prescott (1999), instead, offer a conceptual framework on the comparison between manufacturing and services.

${ }^{5}$ In the context of the role of MNEs in global supply chains Hatani (2009) also explores the possibility of spillover interception and finds that excess inward FDI could hamper the transmission of technological spillovers from foreign firms to the domestic economy.
}

several different services industries and mostly concerns firms providing information-intensive services whose internationalisation mode increasingly entails cross-border export activities (Ball et al., 2008; Rodriguez \& Nieto, 2012) and requires important internal and relational resources (Hitt, Bierman, Uhlenbruck, \& Shimizu, 2006). The data we use are therefore particularly suitable for the analysis of cross-border service trade determinants. Turning to our measure of spillovers through backward linkages, it is built by combining national input-output coefficients and the extent of export openness in downstream manufacturing sectors. This measure also reflects the relevance of the geographical proximity to the customer in facilitating interaction and increasing the chance of benefiting from spillovers stemming from customers' export activity.

While most of the literature on service exports has mainly focused on service multinationals' international expansion and on their role in foreign markets, our study intends to contribute to the international business studies literature by providing systematic evidence on cross-border service exports determinants. More specifically, we generalise the existing evidence from case studies on the importance of buyer-supplier relationships for services firms' cross-border exports across several BS sectors by exploring the importance of the relationship with international manufacturing customers for the BS firms export activity.

Our research aims at carrying important implications for international business practices as well: if export spillovers through vertical linkages with manufacturing customers significantly and systematically ease the BS firms' export activity, BS firms' managers wanting to expand their sales abroad should be concerned about joining networks with internationalised customers to develop the necessary relational capital to enter foreign markets, regardless of the BS supplied.

By highlighting the relevance of the connection between two parts of the economic system - manufacturing and services - that are becoming more and more intertwined (Pla-Barber \& Ghauri, 2012), our study also contributes to the on-going policy debate on countries'development prospects. If the export performance of the service sector is related to the competitiveness of the manufacturing one, the latter's productivity performance may importantly affect the development and internationalisation prospects of the former.

The work is structured as follows: Section 2 presents the background of our work and highlights the testable hypothesis, Section 3 describes our sample and our empirical approach and presents the results and Section 5 discusses the findings and concludes.

\section{Theoretical background and hypothesis}

\subsection{Spillovers through backward linkages in the service firm internationalisation literature}

The traditional view of firm internationalisation hinges on the idea that exporting is a difficult task that has to be learned. A strand of literature has depicted firm internationalisation as an incremental process of acquisition of experiential knowledge first in closer markets to later move to far-off destinations (Johanson \& Vahlne, 1977). The network approach challenges and complements this view by highlighting how information externalities springing from the firm's network may foster and ease its export activity (Axelsson \& Johanson, 1992; Johanson \& Mattsson, 1988). The firm's network is the socio-economic system where the firm operates and includes all the relationships with its suppliers, competitors and customers. Within the network, both economic and non-economic exchanges are important, and both potential and actual relationships matter, 
especially when buyer-supplier linkages are considered (Easton \& Araujo, 1992). ${ }^{6}$ Interaction with the socio-economic environment may become a stepping stone for firm internationalisation, as networks allow for opportunity development that is the process of knowledge and resource combinations to attain new markets or products (Hadjikhani, Ghauri, \& Johanson, 2005). To enter and succeed in a new specific market, a firm must build its own reputation and know more about local customers' tastes and preferences. Indeed, selecting a new market is an information-processing problem, and managers require extensive market information to reduce decision making complexity. However, each firm is constrained in terms of internal resources and building strong and long-lasting relationships with customers, suppliers and partner firms endowed with complementary competence and resources may help finding and exploiting new market opportunities (Andersson, Blankenburg Holm, \& Johanson, 2005). Network components then may fuel the necessary information to dramatically reduce high export entry costs and may help the firm to establish new contacts (Andersen \& Buvik, 2002; Andersen \& Strandskov, 1997; Chetty \& Patterson, 2002; Coviello \& Munro, 1995; Zain \& Ng, 2006). In this respect, network actors' experience abroad serves as an indirect and efficacious learning channel especially when the firm has to overcome the initial uncertainty associated with entering culturally unfamiliar and highly competitive markets. When focusing on the internationalisation process of the BS firm, it is important to recall that, as discussed in the introduction, their foreign market entry is hampered by the intangibility of services and the simultaneity of their production and consumption, which prevent foreign customers from any possible ex ante service quality assessment (Blomstermo \& Sharma, 2003). Furthermore, as noted by Sarathy (1994), the lack of knowledge about foreign cultures and business practices abroad represents an obstacle to effectively tailoring an adequate marketing strategy for services. Then, if exporting is much more difficult for service firms than for manufacturing firms, a service firm's network may be extremely important in easing its internationalisation process.

The hypothesis that spillovers through vertical linkages with customers based in the manufacturing sector favour the export activity of the upstream BS firms, therefore, rests on the proven relevance of buyer-supplier relationships to a firm's competitiveness (Turnbull et al., 1996). Ongoing buyer-supplier relationships allow for a continuous process of opportunity development (Pahlberg \& Thilenius, 2005) and manufacturing buyers may thus represent a natural bridge for the BS firm to gain and strengthen their position in a specific foreign market. Information that stems from actual and potential customers based in the manufacturing sector that are more prone and more used to exporting, due to the higher and easier tradability of their products, may substantially reduce the BS firm's export entry cost. As a consequence, service firms' customers based in the manufacturing sector may dramatically help services firms' management to increase the availability of market information, or in other words to reduce the psychic distance (Brewer, 2007; Johanson \& WiedersheimPaul, 1975).

Spillovers through backward linkages may act through several mechanisms. First, service firms may go abroad to keep up with the international expansion of their own domestic actual and potential customers. As mentioned by Martin et al. (1998), the international expansion of customers may signal a new potential market abroad for the supplier and/or the possibility of being substituted by

\footnotetext{
${ }^{6}$ As a matter of fact, suppliers' attitudes and strategies may be importantly shaped by the potential and actual relationships with potential customers (Turnbull, Ford, \& Cunningham, 1996).
}

foreign suppliers if the buyer plans to move production of goods abroad. ${ }^{7}$ Second, BS firms' actual domestic customers that export to a specific foreign market may act as the best testimonials of the BS firm's service quality, thus favouring the service firm's reputation building and expansion abroad (Sarathy, 1994). Third, both potential and actual domestic customers that export to a specific foreign market may convey to their upstream BS firm the necessary local market knowledge to favour a more rapid service adaptation and may serve as a fundamental informal bridge to build new overseas contacts. In this respect, spillovers through backward linkages may help to reduce the services firm management's psychological distance from the foreign potential customers and/or vice versa. ${ }^{8}$

The above conceptual framework explains how linkages with customers based in manufacturing favour the flow of export spillovers that positively affect the BS firm's entry into the export market. The relevance of such buyer-supplier linkages in favouring the flow of knowledge about the export markets has been empirically investigated by a stream of international business literature testing the importance of network relationships in the internationalisation stories of some specific firms. Even if business studies on services firms highlight that some of them internationalise to seek new markets or to follow a market leader (Erramilli \& Rao, 1990; Hellman, 1996; Majkgard \& Sharma, 1998), the focus on network relationships (Johanson \& Mattsson, 1988; Martin et al., 1998) confirms that the customers of services firms may actually play a vital role in their internationalisation process. Coviello and Munro (1997) show that the internationalisation of small software firms in New Zealand is deeply affected by their partnership with internationalised hardware producers. Thus, customers based in the manufacturing sector act as an informal bridge to penetrate new foreign markets. Their study supports the findings of other business studies showing that spillovers through backward linkages are certainly at work (Bell, 1995; Lindqvist, 1988). Whereas systematic evidence on export spillovers from MNEs and other exporting firms exists and shows their relevance for the manufacturing firm internationalisation process (Greenaway, Sousa, \& Wakelin, 2004; Yilmaz \& Taymaz, 2009) especially when they are destination specific (Bernard \& Jensen, 2004; Clerides, Lach, \& Tybout, 1998; Koenig, 2009; Koenig, Mayneris, \& Poncet, 2010), mainly due to data limitations, a more systematic analysis, beyond the evidence from case studies, of the role of spillovers through backward linkages in the export status of services firms remains missing. ${ }^{9}$

Therefore, based on the theory and the evidence discussed so far, we have the following expectation:

Hypothesis 1. A services firm's export entry in a foreign market is systematically favoured by the export experience in that market

\footnotetext{
${ }^{7}$ Although the Martin et al.'s (1998) empirical framework was specific to the multinational expansion of the firm, the underlying theory is general enough to apply also to exporting.

${ }^{8}$ Psychological distance is a subjective notion and may well be non-symmetrical (Brewer, 2007). In addition, some export stories are initiated by the foreign buyer and as such the psychological distance of the exporter does not affect at all the export market entry whereas the distance perceived by the foreign buyer is determinant (Ellis, 2008)

${ }^{9}$ Nefussi and Schwellnus (2010) represent an exception and prove that internationalisation in services and manufacturing are strictly linked, even if their focus is on FDI and not on the export activity. Close to the findings by Martin et al. (1998) on Japanese components producers' expansion in the U.S. and Canada, they find that the location choices of French services multinationals are affected by the potential demand abroad of French manufacturing affiliates, possibly due the latter's higher preference for French service providers.
} 
gained by the downstream actual and potential customers based in the manufacturing sector.

\subsection{The extent of the spillover effect}

Existing evidence highlights that a smaller percentage of manufacturing firms export to remote markets, thus revealing that the sunk costs of exporting are higher as the destination's geographic distance increases (Lawless, 2010). In principle, the geographical distance should also hamper the trade of services across countries. Moreover, consumer participation in the service provision, together with transportation and communication costs, make the provision of services in foreign markets - both nearby and distant countries - even more difficult (Balabanis, 2000; Head, Mayer, \& Ries, 2009; Manning, Roza, Lewin, \& Volberda, 2013; Sarathy, 1994). Apart from physical distance, cultural differences further exacerbate the extent of sunk costs (Disdier \& Mayer, 2007; Ellis, 2007; Guiso, Sapienza, \& Zingales, 2009; Gullstrand, 2011). In the case of services, culture may indeed have a strong influence on consumers' perception of service quality. Furrer, Shaw-Chimg Liu, and Sudharshan $(2000,2001)$ show that customers from different cultures assign different importance weights to the five dimensions - reliability, responsiveness, assurance, empathy, and tangibles - of the ServQual index (Parasuraman, Zeithaml, \& Berry, $1988,1994)$ for measuring perceived service quality. Therefore, whereas cultural proximity may favour trust and mitigate potential misunderstanding between the BS supplier and foreign buyers, higher cultural distance delivers higher transaction costs due to higher information costs and to the higher difficulty of transferring competences and skills (Lazear, 1999; Leamer \& Storper, 2001; Murray \& Kotabe, 1999). A higher cultural and geographical distance increases the role of psychic distance in hampering the firm's path of international expansion and the extent of resource commitment in foreign markets (Ellis, 2007; Freeman, Giroud, Kalfadellis, \& Ghauri, 2012). It follows that if spillovers matter, their importance should be magnified by the cultural and geographical distance from the destination market (Krautheim, 2012). Therefore, we expect the following:

Hypothesis 2. The higher a destination's physical and cultural distance the higher the positive effect of spillovers through backward linkages on BS firms' export propensity.

Furthermore, for a given psychological/physical/cultural distance a higher market opportunity increases the incentive for the firm to first penetrate that market (Dow, 2000; Ellis, 2008; Johanson \& Wiedersheim-Paul, 1975). If all the uncertainties of internationalisation are removed, managers will prefer larger and richer markets. In particular, high income economies' customers are richer and more sophisticated and tend to have a higher preference for quality and are therefore more keen to pay for it (Arkolakis, 2010; Crinò \& Epifani, 2012). Therefore, international expansion towards large and rich destination markets may represent an unprecedented profit opportunity especially for BS firms, due to the high heterogeneity and differentiation in BS provision. Nevertheless, domestic and foreign competition are likely to be stronger in large advanced markets than in smaller and less developed ones. For Slovenian manufacturers, Damijan, Polanec, and Prasnikar (2004) indeed find evidence of higher sunk entry costs for exporters to advanced economies compared to developing countries. Therefore, the destination market income level represents a further entry barrier for service firms: in most high-income markets, BS provision constitutes a mature activity, and competitive strategies are essentially based on upgrading quality to fulfil customers' expectations (Balabanis, 2000; Sarathy, 1994). Consequently, a richer export destination generally features a denser market, tougher competition and higher entry sunk costs for the BS service firm. Therefore, we expect the following:

Hypothesis 3. For a given cultural and physical distance, the effect of spillovers through backward linkages on BS firms' export propensity is more pronounced and significant in the case of high income level destination markets.

A consequence of Hypotheses 2 and 3 is that entry will be most difficult in markets that are both distant and rich. Therefore we expect:

Hypothesis 4. The effect of spillovers through backward linkages on BS firms' export propensity is yet more pronounced and significant in the case of a high income level export destination market that is both culturally and physically distant.

Finally, with regard to the geographical scope of the spillover, we expect the regional context to play the most prominent role. Even if, in the network perspective, "relational proximity" should be more relevant than "spatial proximity", so that if BS firms sell to customers also outside the region the relevant geographical level could be the national one, the local area is the most effective site, where traded and untraded buyer-seller interdependencies occur and where knowledge spillovers are more likely to occur (Boggs \& Rantisi, 2003). This finding is also corroborated by the robust evidence on the existence of horizontal export spillovers in manufacturing at the local level (Koenig, 2009; Koenig et al., 2010). For service firms, due to the nature of their activity, the local dimension of spillovers may be found to be of further relevance. Indeed, the exploitation of informal contacts and the acquisition of information on foreign destinations and new potential customers abroad may require face-to-face interaction between the service provider and the manufacturing customer.

Therefore, we expect the following:

Hypothesis 5. The relevant geographical scale of backward linkages for the spillover to work is mainly regional.

\section{Data and methods}

\subsection{Sample}

In the following analysis, we use a sample of 1521 business service firms retrieved from the 2001-2003 CAPITALIA survey. ${ }^{10}$ We use the 2003 cross-section because this is the only year for which we have information on firms' export activity. From the original sample we excluded about 300 firms belonging to Section $\mathrm{G}$ (Wholesale and retail trade, repair of motor vehicles, motorcycles and personal and household goods) because being more involved with final consumption would provide us with a too heterogeneous definition of services. Thus, we decided to stick to a narrower definition of our sample which includes the sectors in the survey belonging to the NACE sections I (Transport, storage and communication) and $\mathrm{K}$ (Real estate, renting and business activities), reported in Table 1. After a cleaning procedure ${ }^{11}$ we end up with 897 firms and the upper panel of Table 1 shows their distribution across two digit sectors. Borrowing from the Eurostat (2005) classification of business services our sample is basically made up of some of the Knowledge Intensive Service sectors, KIS, plus the Land Transport (NACE 60) and Logistics (NACE 63). Sticking to the

\footnotetext{
${ }^{10}$ The data are available for free to any researcher requiring access to the Unicredit Bank Research Department.

${ }^{11}$ From the whole initial sample of 1521 firms we drop 240 observations with missing or inconsistent values for the variables of our interest.
} 
Table 1

Distribution of firms.

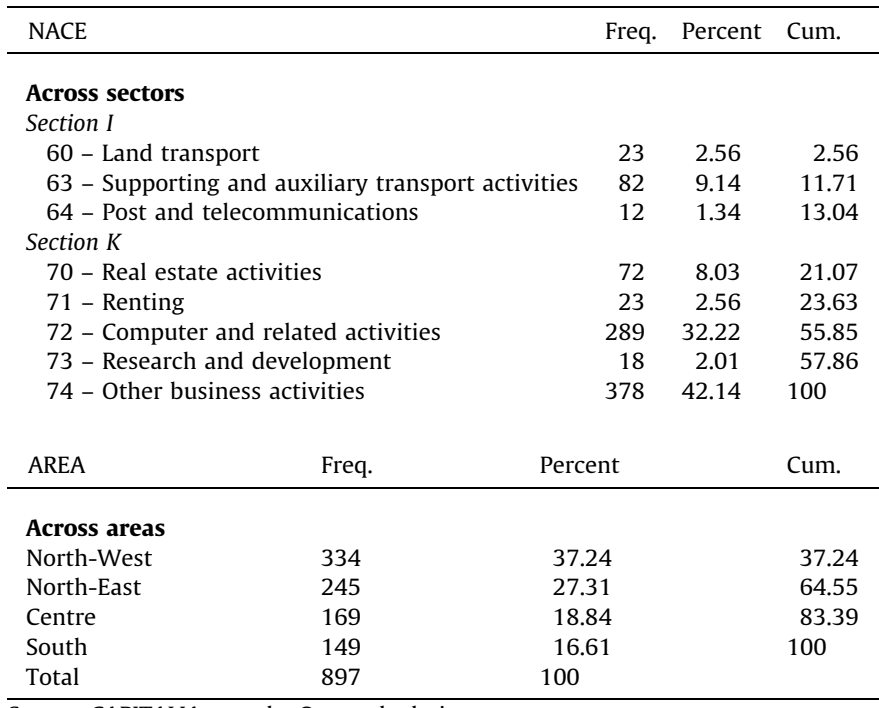

Source: CAPITALIA sample. Own calculations.

definition of KIBS given by the European Commission (2009) about two thirds of our sample is made up of firms belonging to KIBS sectors.

The lower part of Table 1 shows the distribution of firms across the four areas of the Italian territory. The latter is split into 20 (NUTS2) administrative regions, which are commonly grouped into the North-East, North-West, Centre and South regions. ${ }^{12}$ We observe that the highest share of firms is located in the North, especially the North-West, which represents the most developed and industrial area, whereas the South represents only approximately $17 \%$ of the total sample.

\subsection{Measures}

\subsubsection{Dependent variables}

As our focus is on the BS firm's export propensity, from the survey we identify an exporter through the following question:

- In 2003, has the firm sold all or part of its services abroad?

From this definition, we build a dummy variable, Exporter, taking the value 1 for exporters and 0 otherwise, which represents our dependent variable in the baseline empirical model. The WTO GATS defines trade in services into four ways:

- mode 1 - "cross-border supply" when the firms provide the service from their country and customers consume it in their own country;

- mode 2 - "consumption abroad" when the consumers or the firms make use of a service in another country (e.g. tourism);

- mode 3 - "commercial presence" when a foreign company sets up subsidiaries or branches to provide services in another country (e.g. foreign banks setting up operations in a country);

- mode 4 - "presence of natural persons" when individuals travel from their own country to supply services in another one (e.g. fashion models or consultants).

12 The North-East area is composed of Emilia-Romagna, Friuli Venezia Giulia, Trentino Alto Adige, Veneto. The North-West area is composed of Liguria, Lombardia, Piemonte, Valle d'Aosta. The Centre area is made up of Lazio, Marche, Toscana, Umbria. Finally the South is made up of Abruzzo, Basilicata, Calabria, Campania, Molise, Puglia, Sardegna, Sicilia.
As our sample is made up of firms belonging to the transport and business service sectors, all of the four modes can occur even if the presence of a specific question on the FDI status of the firm under section devoted to "Other internationalisation modes" lets us conclude that our export status does not include mode $3 .^{13}$

We do not observe the specific destination country to which the BS service firm exports; nevertheless, the survey provides the following destination areas for firm sales:

- EU-15;

- New EU members ${ }^{14}$;

- Other European countries;

- Extra-European high-income countries;

- Extra-European low-income countries.

To proceed in the test of Hypothesis 2, on the basis of physical and cultural proximity, we then group these areas into the following two main destination markets:

- Europe: including EU-15, New EU members and other European countries:

- Extra-Europe: including extra-European high-income countries and extra-European low-income countries.

We consider European markets not only as geographically but also as culturally closer to Italian firms than extra-European markets, due to the existence of a common cultural background that is shared by European countries and that stems from their long lasting relations in political, economic, cultural and institutional issues. As discussed in our theoretical framework, export spillovers may affect the BS export propensity differently according to the cultural and geographical proximity of the destination market; therefore, we estimate two additional models focusing on a dummy taking the value 1 for exporters to the European countries group and 0 otherwise, Exporter ${ }^{E}$, and a dummy taking the value 1 for exporters to the extra-European countries group and 0 otherwise, Exporter ${ }^{N E}$, as dependent variables. Finally, within each group, we isolate the set of high and low income economies to test Hypotheses 3 and 4 . We then build a further set of dummies to use as the dependent variables: Exporter ${ }^{E H}$ that takes the value 1 for exporters to European high income markets that we identify as the EU15 and 0 otherwise; Exporter ${ }^{E L}$ that takes the value 1 for exporters to European Low income markets that correspond to the New EU members and 0 otherwise ${ }^{15}$; Exporter ${ }^{N E H}$, that takes the value 1 for exporters to extra-European high-income countries and 0 otherwise; and Exporter ${ }^{N E L}$, that takes the value 1 for exporters to extra-European low-income countries and 0 otherwise.

Table 2 shows the share of firms involved in each of the export markets considered in our work by sector of activity and geographical location. As reported in the table, exporters represent $21 \%$ of our sample, most of which reach European destinations (17.5\%) while only $8 \%$ of firms export to extra-European markets, thus revealing that distance hampers service exports. The table also reveals that services firms tend to prefer high income economies. Among the firms exporting to European countries, only a small share reaches the New EU countries and the same is true if we look at the number of extra-European exporters choosing low income destinations. Across sectors, Land Transport and Research and development present the largest share of exporters.

\footnotetext{
${ }^{13}$ As a matter of fact, from the survey it is also possible to identify offshoring and FDI firms which are $2.9 \%$ and $3.4 \%$, respectively, of the total sample.

${ }_{14}^{14}$ New members are the ones entering EU in 2004.

15 As the group of Other European countries include both high and low income economies, for example Switzerland and Norway on one hand and Albania and Montenegro on the other hand, we decided to exclude it from the definition of the European high and low income economies groups.
} 
Table 2

Share of firms involved in export markets by sector and area (\%).

\begin{tabular}{|c|c|c|c|c|c|c|c|c|c|}
\hline \multicolumn{3}{|l|}{ NACE } & \multicolumn{2}{|r|}{ Exporter $^{E}$} & Exporter $^{E H}$ & Exporter $^{E L}$ & Exporter $^{N E}$ & Exporter $^{N E H}$ & Exporter $^{N E L}$ \\
\hline \multicolumn{10}{|c|}{ Across sectors } \\
\hline \multicolumn{10}{|l|}{ Section I } \\
\hline \multicolumn{3}{|c|}{60 - Land Transport } & 47.83 & 47.83 & 47.83 & 0.00 & 8.70 & 8.70 & 0.00 \\
\hline \multicolumn{3}{|c|}{63 - Supporting and auxiliary transport activities } & 19.51 & 15.85 & 15.85 & 2.44 & 7.32 & 4.88 & 4.88 \\
\hline \multicolumn{3}{|c|}{64 - Post and telecommunications } & 8.33 & 8.33 & 8.33 & 0.00 & 8.33 & 8.33 & 8.33 \\
\hline \multicolumn{10}{|c|}{ Section $K$} \\
\hline \multicolumn{3}{|c|}{70 - Real estate activities } & 11.11 & 11.11 & 8.33 & 4.17 & 5.56 & 5.56 & 1.39 \\
\hline \multicolumn{3}{|c|}{71 - Renting } & 17.39 & 17.39 & 13.04 & 0.00 & 0.00 & 0.00 & 0.00 \\
\hline \multicolumn{3}{|c|}{72 - Computer and related activities } & 18.06 & 14.24 & 10.76 & 2.78 & 5.56 & 4.17 & 1.39 \\
\hline \multicolumn{3}{|c|}{73 - Research and development } & 44.44 & 27.78 & 27.78 & 5.56 & 16.67 & 16.67 & 5.56 \\
\hline \multicolumn{3}{|c|}{74 - Other business activities } & 23.54 & 19.58 & 16.67 & 3.17 & 10.58 & 8.99 & 3.97 \\
\hline AREA & Exporter & Exporter $^{E}$ & & $\operatorname{ter}^{E H}$ & Exporter ${ }^{E L}$ & Expor & & Exporter $^{N E H}$ & Exporter $^{N E L}$ \\
\hline \multicolumn{10}{|l|}{ Across areas } \\
\hline North-West & 25.83 & 21.62 & \multicolumn{2}{|c|}{19.22} & 3.30 & 11.71 & \multicolumn{2}{|r|}{11.11} & 2.70 \\
\hline North-East & 20.41 & 17.96 & \multicolumn{2}{|c|}{14.29} & 4.90 & 6.94 & \multicolumn{2}{|r|}{5.71} & 2.86 \\
\hline Centre & 20.71 & 14.79 & \multicolumn{2}{|c|}{11.83} & 1.78 & 7.69 & \multicolumn{2}{|r|}{4.73} & 4.73 \\
\hline South & 12.08 & 10.74 & \multicolumn{2}{|c|}{9.40} & 0.00 & 2.01 & \multicolumn{2}{|r|}{0.67} & 1.34 \\
\hline Total & 21.09 & 17.52 & \multicolumn{2}{|c|}{14.84} & 2.90 & 8.04 & \multicolumn{2}{|r|}{6.70} & 2.90 \\
\hline
\end{tabular}

Source: CAPITALIA. Own calculations.

While for the former European destinations are the most relevant, a non-negligible share of firms in the latter reaches extra-European destinations. Furthermore, as mentioned above, firms located in North-Western Italy, that is the most developed area, are more likely to cross the national borders, even if regional differences in firm export propensity become remarkable for the entry into more competitive and far away countries.

\subsubsection{Independent variables}

Our main independent variable is denoted by BackExp $j$. This variable incorporates the export activity of both the current and potential customers of the service firm and is built as follows:

BackExp $_{j r}=\sum_{h=1}^{n} a_{j h} \times E X P_{h r}+\sum_{s \neq r} \frac{\sum_{h=1}^{n} a_{j h} \times E X P_{h s}}{d_{r s}}$,

the first term in the formula refers to the spillovers originating from downstream manufacturing sectors in region $r$ where the firm is located, whereas the second term refers to the weighted sum of spillovers originating from downstream manufacturing firms located in other regions $s$, each weighted by the inverse of the distance between region $s$ and the firm's region $r .{ }^{16}$ Indeed, existing evidence (Eickelpasch \& Vogel, 2009) suggests that the firm's experience in the national market outside the region is a significant determinant of its export status. It follows that some positive externalities may also originate from other regions. Consequently, we do not restrict the geographical scale of our spillover to be exclusively regional, and we treat the extent of the spillover from other regions as being inversely related to the distance between the firm's location and the region of potential manufacturing customers (Crescenzi et al., 2012; Crescenzi \& Rodriguez-Pose, 2008). ${ }^{17}$ Thus, in a second step we will split the spillover indicator

\footnotetext{
${ }^{16}$ See Crescenzi and Rodriguez-Pose (2008) and Crescenzi, Rodriguez-Pose, and Storper (2012) for the adoption of a similar spillover measure in the analysis of R\&D spillovers.

${ }^{17}$ The relevance of spillovers through backward linkages as dependent on the distance is verified in the literature on the more general topic of spillover effects from competitiveness and innovation (Bottazzi \& Peri, 2003) and mimics the concept of market potential exploited by the New Economic Geography as the source of cross-border - in our context, cross-region - demand linkages (Combes \& Overman, 2004; Midelfart, Overman, \& Redding, 2004).
}

into the regional and extra-regional components to test Hypothesis 5.

In the formula, $a_{j h}$ is retrieved from National Symmetric InputOutput Tables available from ISTAT for 2000 and measures the share of sales from service two-digit NACE sector $j$ to manufacturing NACE subsections $h^{18}$ over total $j$ 's sales. EXP $P_{h r}$ and $E X P_{h s}$ measure the share of total exports ${ }^{19}$ on the total value added of the manufacturing sector $h$, located, respectively in the same region of the service firm - i.e. region $r$ - and in another region, $s \neq r$. Finally, $d_{r s}$ measures the log of distance between region $r$ and region $s .{ }^{20}$

As we expect spillovers to be destination specific, we build additional measures capturing the feedback coming from the export involvement of manufacturing downstream sectors in a specific geographical area. In particular, we focus on the spillovers from the foreign experience of manufacturing customers in European countries, BackExp ${ }^{E}$, extra-European countries, Back$\operatorname{Exp}^{N E}$, and more specifically in the EU15, BackExp ${ }^{E H}$, in the New EU members, BackExp ${ }^{E L}$, and in the extra-European high-, BackExp ${ }^{N E H}$, and low-income countries BackExp ${ }^{N E L}$. These classifications are the same as those used in the definition of the destination specific export status of services firms and are reported in Table A1 in Appendix.

\subsubsection{Control variables}

At the firm level, we include a set of regressors, which are defined in Table A1 and whose descriptive statistics are shown in Table 3 for the total sample and Table A2 in Appendix by subsamples of exporters. Labour productivity reflects the fact that more efficient firms are more likely to export (Melitz, 2003). In addition, to reflect firm- and market-specific knowledge, we

\footnotetext{
${ }^{18}$ While service sectors are defined at two-digit NACE level, manufacturing sectors are defined at sub-section NACE level. We adopt the latter sectoral aggregation for manufacturing sectors because this is the one used by ISTAT in the Regional Accounts, i.e. the data source used to retrieve data of regional-sectoral value added for the computation of the regional-sectoral export openness.

${ }^{19}$ Export data are from COE dataset (ISTAT source), while value added is retrieved from Regional Accounts (ISTAT source). We cannot use output at the denominator (as is usual in literature) because this variable is not available for 8 regions due to confidentiality reasons.

${ }^{20}$ We take the log of the distance to allow our measure not to be dependent on the scale adopted (e.g. km vs. miles). The distance between region $r$ and region $s$ is the road distance between regional capitals and is retrieved from the Istituto Geografico De Agostini. For the islands we have imputed $100 \mathrm{~km}$ for each hour of navigation.
} 
Table 3

Descriptive statistics.

\begin{tabular}{|c|c|c|c|c|c|}
\hline Variable & Obs. & Mean & Std. Dev. & Min & Max \\
\hline$L P$ & 894 & 3.66 & 0.92 & -2.46 & 7.83 \\
\hline Age & 878 & 16.14 & 12.00 & 1 & 119 \\
\hline$L a b$ & 894 & 3.15 & 1.15 & 1.61 & 7.34 \\
\hline FDIOFF & 897 & 0.06 & 0.23 & 0 & 1 \\
\hline Group & 896 & 0.26 & 0.44 & 0 & 1 \\
\hline Sale $_{\text {nat }}$ & 886 & 45.34 & 42.70 & 0 & 100 \\
\hline Sell Large & 890 & 0.51 & 0.50 & 0 & 1 \\
\hline Sell & 890 & 0.59 & 0.49 & 0 & 1 \\
\hline Inno $_{\text {Serv }}$ & 897 & 0.39 & 0.49 & 0 & 1 \\
\hline Inno $_{\text {Proc }}$ & 897 & 0.28 & 0.45 & 0 & 1 \\
\hline
\end{tabular}

include age and its squared value, the share of sales in the national market outside the region and its squared value, a dummy for sellers to large manufacturing firms and a dummy for sellers to small and medium enterprises. We consider this set of dummy variables as essential for identifying and isolating the spillovers from the export involvement of downstream manufacturing firms, as they allow to control for firms' overall experience with manufacturing customers. The squared terms of age and of sales in the national market are intended to allow for a non-linear relationship between experience and export probability under the hypothesis that the former positively affects the latter, although at a declining rate. We also control for size and its square value to reflect scale economies, foreign investments and offshoring activity, the firm's belonging to a group, and service and process innovation activity. At the regional level, we include the regional labour productivity in manufacturing, the home region (NorthWest, North-East, Centre and South) and two-digit NACE sector fixed effects to account for regional and activity heterogeneity.

\subsubsection{Econometric model}

The basic empirical model follows from the notion that export information spillovers from downstream manufacturing sectors reduce the sunk cost of exporting (Roberts \& Tybout, 1997). Firm $i$ exports if its expected profits in the export market $\left(\Pi^{\exp } / q\right)$ with $\Pi^{\text {exp }}$ measuring profits from exports and $q$ measuring the interest rate, are higher than the sunk entry cost, $F$

$$
\frac{\Pi^{\exp }}{q}>F
$$

rearranging and taking the logs, the probability for firm $i$ to be a service exporter may be written as

$$
\operatorname{Pr}\left(\text { Export }_{i}>0\right)=\operatorname{Pr}\left(\ln \Pi_{i}^{\text {exp }}-\ln q-\ln F>\epsilon_{i}\right)
$$

where $\epsilon_{i}$ is an idiosyncratic error term. As already mentioned, we assume that the sunk costs of exports are a function of spillovers through backward linkages, which vary by service sector $j$ and region $r$, then $F=g\left(B_{a c k E x p}{ }_{j r}\right)$. Thus, the final estimation equation is as follows:

$$
\text { Export }_{i j r}=\alpha X_{i}+\gamma \text { BackExp }_{j r}+\beta L P_{\text {Reg } r}+\mu_{j}+\phi_{a}+\epsilon_{i j r}
$$

where $X_{i}$ is the vector of firm level controls, $L P_{\operatorname{Reg} r} r$ is the regional labour productivity in manufacturing, $\phi_{a}$ and $\mu_{j}$, respectively represent the area (North-West, North-East, Centre and South) and two-digit NACE sector fixed effects. Under the assumption that the error $\epsilon_{i}$ is normally distributed, we may estimate Eq. (2) with a probit model. Because our backward spillover varies by region and sector, we clustered the observations at the region and 2-digit sector level to correct for the downward bias in the estimation of standard-errors that may arise when individual variables are regressed on aggregate variables (Moulton, 1990).

Before moving to the presentation of the results in the next section, it is worth discussing some drawbacks of our estimation framework. Unfortunately, we are not completely able to identify causal effects of our right-hand-side variables and our spillover measure on the probability of exporting due to our focus on a cross-section of firms and to a lack of valid instruments. Nevertheless, service firms usually begin as local - be they regional or national - firms focused on serving local customers, and it is unlikely that their status as exporters causes local manufacturing firms to go abroad. In addition, we focus on the feedback from the entire population of actual and potential customers - i.e. downstream manufacturing sectors - and not on feedback from the effective customers of the service firm. Therefore, it is unlikely that the overall downstream sector's performance and characteristics are affected by an individual service firm's export propensity. However, we try to consider the possibility of reverse causality in the robustness checks including the spillover measure in $(t-2)$, the first year of the survey, and controlling for other possible omitted region and region-sector variables that may drive the export propensity of service firms beyond our spillover through backward linkage measure.

A second problem in the identification of the spillover effect concerns the fact that sorting may be at play: if a service firm willing to become an exporter decides to settle in an area characterised by high export intensity among manufacturing customers to reap all the benefits we have discussed above, we may observe a larger presence of exporters in regions with high manufacturing export intensity regardless of the degree of the spillover effect at play. To mitigate this issue, in the empirical model, we include one dummy for each of the four areas displayed in Table 1 and the average productivity of manufacturing firms in the region, $L P_{\text {Reg, }}$, which is intended to reflect the local average manufacturing efficiency that may drive the probability of exporting. Therefore, in the robustness checks, we consider the export openness of the administrative region, which represents the geographical variability of our spillover measure.

However, we leave a more detailed detection of the causal nexus to future research when a panel data set on service firms will be available, and, to be cautious, we will conservatively interpret our results in terms of correlation. Although this may be limiting, we believe that it may be insightful and disclose a new research hypothesis to investigate.

\section{Results}

This section presents the results from the estimation of the probit model 2. Table 4 provides a test of Hypothesis 1 . In the first column the export market is considered as a whole, while in the remaining columns the dependent variable is the probability to export to a specific destination and, as a consequence, the spillover measure is destination specific. Thus, columns 2,3 and 4 , respectively, test the role of manufacturing customers export experience in the closer European area and in the two sub-groups of high and low income economies within Europe for the BS firm probability to export to those markets. By the same token, columns 5,6 and 7, respectively, test the spillover significance for exporting to the whole of the far-off extra-European markets and to the subgroups of high and low income economies outside Europe. The comparison between columns 2 and 5, thus, represents a test of Hypothesis 2, while the comparison of columns 3/4-6/7 is the test of 3. Column 7 is the test of Hypothesis 4. Finally, by splitting the spillover measure in regional and national components, Table 5 contains the direct test of Hypothesis 5 on the relevant spillover geographical scale. 
Table 4

Spillovers from the export experience of downstream manufacturing customers.

\begin{tabular}{|c|c|c|c|c|c|c|c|}
\hline & \multicolumn{7}{|c|}{ Dependent variable } \\
\hline & Exporter & Exporter $^{E}$ & Exporter $^{E H}$ & Exporter ${ }^{E L}$ & Exporter $^{N E}$ & Exporter $^{N E H}$ & Exporter $^{N E L}$ \\
\hline \multicolumn{8}{|l|}{ Controls } \\
\hline \multirow[t]{2}{*}{$L P$} & 0.025 & 0.017 & -0.016 & -0.017 & $0.165^{*}$ & $0.188^{* *}$ & 0.132 \\
\hline & {$[0.056]$} & [0.063] & [0.066] & [0.099] & [0.092] & [0.095] & [0.108] \\
\hline \multirow[t]{2}{*}{ Age } & $0.013^{*}$ & 0.010 & 0.005 & 0.024 & -0.003 & -0.012 & $0.052^{* *}$ \\
\hline & {$[0.008]$} & [0.009] & {$[0.010]$} & [0.049] & [0.009] & {$[0.008]$} & {$[0.023]$} \\
\hline \multirow[t]{2}{*}{$A g e^{2}$} & 0.000 & 0.000 & 0.000 & -0.002 & 0.000 & $0.000^{*}$ & $-0.001^{*}$ \\
\hline & {$[0.000]$} & {$[0.000]$} & {$[0.000]$} & [0.002] & {$[0.000]$} & {$[0.000]$} & {$[0.000]$} \\
\hline \multirow[t]{2}{*}{$L a b$} & 0.466 & 0.457 & 0.304 & 0.543 & 0.129 & 0.066 & 0.341 \\
\hline & {$[0.304]$} & {$[0.290]$} & {$[0.320]$} & {$[0.452]$} & {$[0.319]$} & {$[0.348]$} & {$[0.524]$} \\
\hline \multirow[t]{2}{*}{$L a b^{2}$} & $-0.067^{*}$ & -0.065 & -0.045 & -0.054 & -0.022 & -0.008 & -0.062 \\
\hline & {$[0.040]$} & {$[0.040]$} & [0.043] & [0.053] & [0.039] & {$[0.042]$} & {$[0.070]$} \\
\hline \multirow[t]{2}{*}{ FDIOFF } & $0.864^{* * *}$ & $0.490^{*}$ & 0.216 & $0.698^{* *}$ & $0.888^{* * * *}$ & $0.842^{* * * *}$ & $0.914^{* * * *}$ \\
\hline & {$[0.234]$} & {$[0.268]$} & [0.253] & {$[0.346]$} & {$[0.242]$} & {$[0.268]$} & {$[0.210]$} \\
\hline \multirow[t]{2}{*}{ Group } & -0.041 & 0.079 & 0.135 & -0.291 & -0.090 & -0.054 & $-0.651^{* *}$ \\
\hline & [0.148] & [0.153] & [0.153] & [0.305] & [0.160] & [0.155] & [0.318] \\
\hline \multirow[t]{2}{*}{ Sale $_{\text {nat }}$} & $0.048^{* * * *}$ & $0.047^{* * * * *}$ & $0.048^{* * * *}$ & $0.040^{* * * * *}$ & $0.046^{* * * *}$ & $0.039^{* * * *}$ & $0.037^{* * * *}$ \\
\hline & [0.005] & [0.006] & [0.006] & [0.007] & [0.008] & [0.009] & [0.009] \\
\hline \multirow{2}{*}{ Sale $_{\text {nat }}^{2}$} & $-0.000^{* * *}$ & $-0.000^{* * *}$ & $-0.000^{* * *}$ & $-0.000^{* * *}$ & $-0.000^{* * *}$ & $-0.000^{* * *}$ & $-0.000^{* * * *}$ \\
\hline & {$[0.000]$} & {$[0.000]$} & {$[0.000]$} & {$[0.000]$} & {$[0.000]$} & {$[0.000]$} & {$[0.000]$} \\
\hline \multirow[t]{2}{*}{ Sell ${ }_{\text {Large }}$} & $0.445^{* * * *}$ & $0.294^{* *}$ & $0.332^{* * * *}$ & $0.617^{* * * *}$ & $0.629^{* * * *}$ & $0.719^{* * * *}$ & $0.504^{* * * *}$ \\
\hline & [0.115] & [0.118] & [0.125] & [0.232] & [0.217] & {$[0.226]$} & [0.195] \\
\hline \multirow[t]{2}{*}{ Sell $_{S M E S}$} & -0.106 & 0.009 & 0.066 & -0.051 & $-0.371^{* * *}$ & $-0.343^{* * *}$ & -0.246 \\
\hline & [0.099] & [0.112] & [0.134] & {$[0.268]$} & {$[0.117]$} & [0.117] & [0.166] \\
\hline \multirow[t]{2}{*}{ Inno $_{\text {serv }}$} & -0.041 & -0.014 & -0.179 & 0.261 & -0.078 & -0.165 & -0.032 \\
\hline & [0.104] & [0.113] & [0.122] & [0.229] & [0.121] & [0.153] & [0.217] \\
\hline \multirow[t]{2}{*}{ Inno $_{\text {proc }}$} & 0.133 & 0.114 & 0.218 & -0.364 & 0.177 & 0.176 & 0.071 \\
\hline & [0.129] & [0.124] & [0.155] & {$[0.252]$} & [0.192] & [0.205] & [0.185] \\
\hline \multirow[t]{2}{*}{$L P_{R e g}$} & $1.210^{*}$ & 1.044 & 1.006 & -0.145 & $1.763^{* *}$ & -0.213 & $2.500^{* *}$ \\
\hline & [0.651] & [0.660] & {$[0.730]$} & [1.457] & [0.793] & [1.087] & [1.265] \\
\hline \multicolumn{8}{|c|}{ Independent variables } \\
\hline \multirow[t]{2}{*}{ BackExp } & -0.010 & & & & & & \\
\hline & {$[0.014]$} & & & & & & \\
\hline \multirow[t]{2}{*}{ BackExp ${ }^{E}$} & & 0.001 & & & & & \\
\hline & & {$[0.021]$} & & & & & \\
\hline \multirow[t]{2}{*}{ BackExp $^{E H}$} & & & -0.003 & & & & \\
\hline & & & {$[0.026]$} & & & & \\
\hline BackExp ${ }^{E L}$ & & & & 0.355 & & & \\
\hline & & & & {$[0.240]$} & & & \\
\hline BackExp $^{N E}$ & & & & & $0.112^{*}$ & & \\
\hline & & & & & {$[0.057]$} & & \\
\hline BackExp ${ }^{N E H}$ & & & & & & $0.561^{* * *}$ & \\
\hline & & & & & & {$[0.211]$} & \\
\hline BackExp ${ }^{N E L}$ & & & & & & & 0.090 \\
\hline & & & & & & & {$[0.144]$} \\
\hline Observations & 868 & 868 & 868 & $675^{a}$ & $846^{\mathrm{a}}$ & $846^{\mathrm{a}}$ & $823^{a}$ \\
\hline Pseudo- $R^{2}$ & 0.191 & 0.159 & 0.168 & 0.22 & 0.237 & 0.259 & 0.25 \\
\hline Wald $\mathrm{Chi}^{2}$ & 397.3 & 212.2 & 232.3 & 564.3 & 444.1 & 838.3 & 1248 \\
\hline Log-likelihood & -361.8 & -340.1 & -304.9 & -83.41 & -186 & -158.6 & -86.53 \\
\hline
\end{tabular}

Robust standard errors in brackets are clustered by region-sector pair. Area and 2-digit sector dummies are included in every regressions.

a The drop of observations is because some sector and area dummies perfectly predict the export status.

${ }^{*} p<.10$.

${ }^{* *} p<.05$.

${ }^{* * *} p<.01$.

Turning to the interpretation of the estimates, with regard to the firm-level characteristics, we find that firm productivity, $L P$, only becomes significant when distant and more difficult markets must be reached and that the firm's age and size, Age and Lab, are not always significant, whereas making business with large manufacturing firms (Sell $\left.l_{\text {Large }}\right)$ and acquiring experience in the national market outside the local one (Sale nat $_{\text {) }}$ are positively and significantly related to the probability of being a service exporter. Focusing, now, on our variable of interest in the first model for the general export status determinants (Table 4, column 1), we find that overall export openness of downstream manufacturing sectors is not signifi- cant. Thus Hypothesis 1 is not valid in general when considering the export market as a whole. When splitting export markets by cultural and geographical distance, the comparison of results displayed in columns 2 and 5 validates our Hypothesis 2, as the spillover measure significance is higher when exporting to extra-European markets. 3, instead, on the higher general relevance of the spillover to reach high income economies for a given distance, is not confirmed, while our expectation on the spillover being particularly effective in reaching markets that are both high income and distant is confirmed. Our findings support the relevance of destination specific spillover for both exports to extra-European markets and exports to high-income 
Table 5

Backward Spillovers from export: regional and national scope.

\begin{tabular}{|c|c|c|c|c|c|c|c|}
\hline & \multicolumn{7}{|c|}{ Dependent variable } \\
\hline & Exporter & Exporter $^{E}$ & Exporter $^{E H}$ & Exporter $^{E L}$ & Exporter $^{N E}$ & Exporter $^{N E H}$ & Exporter $^{N E L}$ \\
\hline \multirow[t]{2}{*}{$L P$} & 0.029 & 0.020 & -0.015 & -0.020 & $0.167^{*}$ & $0.186^{* *}$ & 0.135 \\
\hline & {$[0.057]$} & {$[0.064]$} & {$[0.067]$} & {$[0.100]$} & {$[0.091]$} & [0.095] & {$[0.111]$} \\
\hline \multirow[t]{2}{*}{ Age } & $0.013^{*}$ & 0.01 & 0.005 & 0.025 & -0.003 & -0.012 & $0.057^{* * *}$ \\
\hline & [0.007] & [0.009] & {$[0.010]$} & {$[0.049]$} & [0.009] & {$[0.008]$} & {$[0.023]$} \\
\hline \multirow[t]{2}{*}{$A g e^{2}$} & 0.000 & 0.000 & 0.000 & -0.002 & 0.000 & $0.000^{*}$ & $-0.001^{* *}$ \\
\hline & {$[0.000]$} & {$[0.000]$} & {$[0.000]$} & {$[0.002]$} & {$[0.000]$} & {$[0.000]$} & {$[0.000]$} \\
\hline \multirow[t]{2}{*}{$L a b$} & 0.460 & 0.454 & 0.302 & 0.528 & 0.124 & 0.069 & 0.298 \\
\hline & {$[0.304]$} & {$[0.290]$} & [0.319] & {$[0.458]$} & [0.319] & {$[0.348]$} & [0.527] \\
\hline \multirow[t]{2}{*}{$L a b^{2}$} & $-0.066^{*}$ & -0.065 & -0.044 & -0.051 & -0.021 & -0.008 & -0.056 \\
\hline & {$[0.040]$} & {$[0.040]$} & {$[0.043]$} & [0.053] & [0.039] & {$[0.042]$} & {$[0.071]$} \\
\hline \multirow[t]{2}{*}{ FDIOFF } & $0.836^{* * * *}$ & $0.460^{*}$ & 0.199 & $0.734^{* * *}$ & $0.878^{* * *}$ & $0.846^{* * *}$ & $0.852^{* * * *}$ \\
\hline & {$[0.231]$} & [0.268] & {$[0.251]$} & [0.337] & [0.247] & [0.269] & {$[0.215]$} \\
\hline \multirow[t]{2}{*}{ Group } & -0.045 & 0.077 & 0.134 & -0.261 & -0.089 & -0.054 & $-0.659^{* *}$ \\
\hline & [0.148] & {$[0.152]$} & [0.152] & [0.298] & {$[0.160]$} & {$[0.154]$} & [0.319] \\
\hline \multirow[t]{2}{*}{ Sale $_{\text {nat }}$} & $0.049^{* * *}$ & $0.048^{* * * *}$ & $0.048^{* * *}$ & $0.039^{* * * *}$ & $0.046^{* * *}$ & $0.039^{* * * *}$ & $0.039^{* * *}$ \\
\hline & {$[0.005]$} & {$[0.006]$} & {$[0.006]$} & {$[0.007]$} & {$[0.008]$} & [0.009] & [0.009] \\
\hline \multirow[t]{2}{*}{ Sale $_{\text {nat }}^{2}$} & $-0.000^{* * * *}$ & $-0.000^{* * * *}$ & $-0.000^{* * * *}$ & $-0.000^{* * * *}$ & $-0.000^{* * * *}$ & $-0.000^{* * * *}$ & $-0.000^{* * * *}$ \\
\hline & {$[0.000]$} & {$[0.000]$} & {$[0.000]$} & {$[0.000]$} & {$[0.000]$} & {$[0.000]$} & {$[0.000]$} \\
\hline \multirow[t]{2}{*}{ Sell ${ }_{\text {Large }}$} & $0.438^{* * * *}$ & $0.287^{* *}$ & $0.326^{* * *}$ & $0.627^{* * * *}$ & $0.629^{* * * *}$ & $0.718^{* * *}$ & $0.520^{* * *}$ \\
\hline & [0.115] & [0.117] & [0.124] & [0.233] & {$[0.216]$} & {$[0.226]$} & [0.193] \\
\hline \multirow[t]{2}{*}{ Sell $_{S M E S}$} & -0.109 & 0.005 & 0.066 & -0.039 & $-0.372^{* * *}$ & $-0.345^{* * *}$ & -0.269 \\
\hline & [0.099] & [0.111] & [0.133] & [0.273] & [0.117] & {$[0.117]$} & [0.167] \\
\hline \multirow[t]{2}{*}{ Inno $_{\text {serv }}$} & -0.059 & -0.032 & -0.188 & 0.293 & -0.091 & -0.155 & -0.098 \\
\hline & [0.107] & [0.117] & {$[0.124]$} & [0.243] & [0.125] & [0.153] & {$[0.222]$} \\
\hline \multirow[t]{2}{*}{ Inno $_{\text {proc }}$} & 0.144 & 0.123 & 0.223 & -0.39 & 0.184 & 0.172 & 0.103 \\
\hline & [0.129] & [0.126] & [0.156] & [0.258] & [0.192] & [0.206] & [0.191] \\
\hline$L P_{\text {Reg }}$ & $1.412^{* *}$ & $1.280^{*}$ & 1.171 & -0.219 & $1.793^{* * *}$ & -0.264 & $2.599^{*}$ \\
\hline & [0.677] & [0.717] & [0.789] & [1.505] & [0.795] & [1.080] & [1.332] \\
\hline Independent va & & & & & & & \\
\hline BackExp $_{\text {Reg }}$ & 0.004 & & & & & & \\
\hline & {$[0.016]$} & & & & & & \\
\hline BackExp OthReg & $-0.047^{*}$ & & & & & & \\
\hline 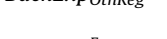 & {$[0.025]$} & & & & & & \\
\hline BackExp ${ }_{\text {Reg }}^{E}$ & & 0.012 & & & & & \\
\hline & & [0.023] & & & & & \\
\hline BackExp EthReg & & -0.043 & & & & & \\
\hline & & [0.037] & & & & & \\
\hline BackExp ${ }_{R e g}^{E H}$ & & & 0.006 & & & & \\
\hline & & & {$[0.030]$} & & & & \\
\hline BackExp OthReg & & & -0.038 & & & & \\
\hline & & & [0.053] & & & & \\
\hline BackExp ${ }_{\text {Reg }}^{E L}$ & & & & 0.942 & & & \\
\hline & & & & [0.628] & & & \\
\hline BackExp OthReg & & & & 2.666 & & & \\
\hline & & & & [2.160] & & & \\
\hline BackExp ${ }_{R e g}^{N E}$ & & & & & $0.120^{* *}$ & & \\
\hline & & & & & {$[0.060]$} & & \\
\hline BackExp OthReg & & & & & 0.017 & & \\
\hline & & & & & [0.134] & & \\
\hline BackExp $p_{R e g}^{N E H}$ & & & & & & $0.564^{* * *}$ & \\
\hline & & & & & & {$[0.214]$} & \\
\hline BackExp NEH & & & & & & $0.796^{*}$ & \\
\hline & & & & & & {$[0.434]$} & \\
\hline BackExp NeL & & & & & & & 0.055 \\
\hline & & & & & & & [0.127] \\
\hline BackExp OthReg & & & & & & & $-0.546^{*}$ \\
\hline & & & & & & & {$[0.326]$} \\
\hline Observations & 868 & 868 & 868 & $675^{\mathrm{a}}$ & $846^{\mathrm{a}}$ & $846^{\mathrm{a}}$ & $823^{a}$ \\
\hline Pseudo- $R^{2}$ & 0.193 & 0.160 & 0.169 & 0.224 & 0.238 & 0.259 & 0.258 \\
\hline Wald $\mathrm{Chi}^{2}$ & 393.3 & 226.7 & 229.8 & 478.5 & 453.8 & 906.9 & 1185 \\
\hline Log-likelihood & -360.9 & -339.5 & -304.6 & -82.93 & -185.9 & -158.5 & -85.65 \\
\hline
\end{tabular}

Robust standard errors in brackets are clustered by region-sector pair. Area and 2-digit sector dummies are included in every regressions. E: exports to European countries; $N E$ : exports to extra-European countries; $N E H$ : exports to high income extra-European countries.

a The drop of observations is because some sector and area dummies perfectly predict the export status.

${ }^{*} p<.10$.

** $p<.05$.

$p<.01$. 
extra-European markets, and in the latter case, the significance and magnitude of the effect are higher. ${ }^{21}$ The lack of any significant spillover effect for the European economies and, more specifically, for the high income ones may stem from the high degree of integration existing among economies within Europe.

Now, to test our last hypothesis on the relevant geographical scale of the spillover through backward linkages between manufacturing and services in greater detail, we split the measure in formula 1 into its first term, BackExp $p_{\text {ege }}$, referring to spillovers from the same region of the BS firm, and its second term,

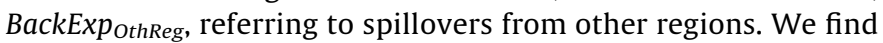
in Table 5 that although the significance level of the spillover through backward linkages from other regions disappears when all the extra-European markets are considered, both measures are positively related to the probability of exporting to high-income extra-European markets, even if the significance of the spillover from other regions is low. Therefore, there is mainly a local regional - destination specific backward spillover at play. In addition, there appears to be some evidence supporting a positive influence of the international involvement of manufacturing customers located outside the region when service firms penetrate developed and distant countries. ${ }^{22}$ Additionally, some evidence seems to emerge on the positive role of the international involvement of manufacturing customers located outside the region, when service firms penetrate far away developed countries.

Coefficients in columns 5 and 6 in the Table appear to suggest a stronger relationship between the regional export spillover and the propensity to export economies outside Europe, especially to high-income extra-European markets. This feature is confirmed by the estimation of marginal effects. The latter reveals that a one-percentage-point change in the regional spillover measure is related to a one- to three-percentage-point increase in the probability of exporting to extra-European and high-income extra-European markets, respectively. In addition, the computation of marginal effects from coefficients in column 6 reveals that the magnitude of the spillover effect from other regions is slightly higher than the regional one. However, once sector and area heterogeneity are accounted for - as in our empirical model - the range of variability of the latter spillover measure is higher. ${ }^{23}$ This finding implies that, considering the actual relevant variability range of our indicators, the spillover from the same region explains a much larger share of the observed variation in export probability compared to the spillover from other regions. Therefore, we conclude that the regional scale is the most important one, thus confirming our fifth and last hypothesis.

\subsection{Robustness checks}

The above findings have proved to be robust to several checks reported in Table A3 in Appendix. Because our main results concern extra-European countries, for the sake of brevity, robustness is shown only for spillovers specific to these destinations. ${ }^{24}$ Columns 1 to 8 in Table A3 all concern the potential omitted variable bias of our estimates. First, we include a firm dummy for foreign ownership, ForOwn, (columns 1 and 2 ) for which our results remain unchanged. We then add a

\footnotetext{
21 The importance of the destination specific spillovers mimics the findings by Koenig (2009) on French manufacturing exporters.

22 This result holds when we only include the regional spillover in the regression. ${ }^{23}$ The average difference between the lowest and the highest values of the regional spillover measure for High Income extra-European countries is about 2 percentage points, while the same difference for the spillover measure from other regions is about 0.44 points
}

set of region- and region-sector-level variables: the downstream manufacturing sector market density, BackN, measured as the logarithm of the number of firms in the downstream manufacturing sector in the region, ${ }^{25}$ (columns 3 and 4); regional GDP, GDP Reg, (columns 5 and 6) and the regional export openness, ExpOp $p_{\text {Reg, }}$ in the following two columns. BackN has the same region-sector variability of our variables of interest and is intended as a proxy of the efficiency of downstream manufacturing sectors that could stimulate efficiency and high quality in services and, thus, enhance the exploitation of scale economies, helping service firms in becoming exporters. $G D P_{\text {Reg }}$ and $\mathrm{ExpOp}_{\text {Reg }}$ are region-level controls, meant to capture the size of the regional economy and its overall propensity to export. When we include these controls, we confirm our results in terms of the significance of destination specific spillover measures for export entry in the sub-group of high-income extra-European countries. On the contrary, the export spillovers for export propensity towards the entire group of extra-European economies - regardless of their income level - are no longer significant. These results may hint at the fact that, when all relevant observables are considered, spillovers through backward linkages are indeed fruitful more for penetrating developed markets that are thicker, more competitive and, possibly, more demanding in terms of services quality. In addition, we show that all region- and region-sector-level controls prove to be non-significant.

Finally, to mitigate the issue of the endogeneity of our variables of interest, we include their second lag - i.e. their value in 2001 - in the last two columns of the table. Results indicate that once simultaneity is accounted for, only the spillover from the same region remains significant. The causal link between downstream manufacturing export openness and the service firms' propensity to export could then matter significantly at the local level. The effectiveness of the destination specific export spillover may be hindered by the lack of face-to-face interaction between the service provider and the manufacturing customer. This may indeed be the case when engaging customers located in other regions. $^{26}$

\section{Conclusion}

With this paper, we contribute to the international business literature by investigating the relevance of network relationships for the BS firm's cross-border export activity. In particular, by exploiting a fairly large sample of Italian service firms, we implement a systematic and quantitative analysis of the role of internationalised manufacturing customers in favouring BS providers' access to international markets. Our evidence corroborates and generalises the findings from business case studies (Bell, 1995; Coviello \& Munro, 1997) across a heterogeneous set of BS sectors. We show that export spillovers through backward linkages are only active when they are destination specific, i.e. when spillovers stem from actual and potential manufacturing customers' export activity in the same destination area to which the BS

\footnotetext{
24 The remaining results are available upon request.

25 In order to compute BackN, we make use of Eq. 1, where the regional and sectoral export openness is replaced by the number of firms in the downstream sector and in the region.

${ }^{26}$ We also run another set of controls excluding all potentially non-tradable sectors and substituting the regional GDP with the regional population. Finally, following Javorcik (2004) for the computation of spillover measures we use the input-output coefficients built as proportion of the sectoral output supplied to manufacturing sector excluding products supplied for final consumption, that is taking into account (at the denominator) the total sales of intermediates, instead of the total production of the sector. The findings mimic the results shown in the text. We do not show these sets of estimates here for the sake of brevity, however they are readily available from the authors upon request.
} 
firm exports. Furthermore, their relevance is higher for accessing more distant and high-income countries. As a matter of fact, we first find that the spillover effect is significant only for service firms' export propensity to countries outside Europe, which represent more geographically and culturally remote markets. Second, the information on the export experience stemming from downstream manufacturing firms is found to be much more important as a facilitator of a firm's entry into far-off high-income destinations, which are characterised by more competitive pressure and demand for higher quality. The latter result is confirmed across all of our robustness checks. All this evidence hints at heterogeneous export entry costs according to the destination markets' characteristics. Finally, we find that the geographical scale of knowledge flows, driving the interdependence between manufacturing and services' internationalisation, is mainly local.

If one could interpret our main findings as causal effects, our hypothesis of spillovers through local backward linkages as a foundation of services firms' success in foreign markets would be confirmed by the data, suggesting that internationally competitive services require competitive (and thus internationalised) manufacturing. Some policy directions may then follow for the Italian case, where the on-going stagnant manufacturing productivity may hinder firms' competitiveness in the upstream service sector as well. In addition, as knowledge-intensive business services are the new growth-creating sectors, the lack of industrial development in lagging regions may prevent the local growth of such services, thus dooming these areas to experience an increasingly pronounced competitive gap compared to the other regions. In this regard, the severe economic disparities across Italian regions make the search for a new development agenda for the "Mezzogiorno" even more urgent.
From our study we can also perceive some future avenues for research related to the analysis of spillovers originating from other internationalisation strategies. Especially, the presence of multinationals in the local market may represent an important driver for the international success of domestic firms in the same sector or in upstream/downstream sectors. The investigation of such linkages may give important insights and stimulate policy debate.

\section{Acknowledgements}

Financial support received from the Italian Ministry of Education, University and Research (Scientific Research Programs of National Relevance 2007 on European Union Policies, Economic and Trade Integration Processes and WTO negotiation-PUE\&PIEC) is gratefully acknowledged. We are grateful to participants at the 11th ETSG Conference held in Rome in September 2009, at the workshop on "The Internationalisation of Services" held at the DIW in Berlin in June 2009, at the 6th Danish International Workshop, held at Aarhus School of Business in June 2010, at the Italian Trade Study Group Workshop in Reggio Calabria in July 2010, at the SIE Conference, held in Catania in October 2010 and the Conference on "The Role of Business Services for Innovation, Internationalisation and Growth", held in Rome in December 2010. We also thank participants in the 7th annual FREIT-LETC conference for their comments on a companion paper which resulted in useful suggestions for this research. Finally, thanks to Alberto Russo for his helpful comments on this version of the paper.

\section{Appendix}

See Tables A1-A3.

Table A1

Export determinants.

\begin{tabular}{|c|c|}
\hline Variable & Description \\
\hline \multicolumn{2}{|c|}{ Independent variables } \\
\hline BackExp & Backward spillover \\
\hline BackExp & Backward spillover stemming from the export experience in European countries of manufacturing customers \\
\hline BackExp ${ }^{E H}$ & Backward spillover stemming from the export experience in EU15 countries \\
\hline BackExp ${ }^{E L}$ & Backward spillover stemming from the export experience in new EU members \\
\hline BackExp $^{N E}$ & Backward spillover stemming from the export experience in extra-European countries of manufacturing customers \\
\hline BackExp ${ }^{N E H}$ & Backward spillover stemming from the export experience in high income extra-European countries of manufacturing customers \\
\hline BackExp ${ }^{N E L}$ & Backward spillover stemming from the export experience in low income extra-European countries of manufacturing customers \\
\hline BackExp Reg & $\begin{array}{l}\text { Backward spillover stemming from the export experience in European countries of manufacturing customers that are located in the same region of } \\
\text { the BS firm }\end{array}$ \\
\hline BackExp ${ }_{R e g}^{E H}$ & $\begin{array}{l}\text { Backward spillover stemming from the export experience in EU15 countries of manufacturing customers that are located in the same region of the } \\
\text { BS firm }\end{array}$ \\
\hline BackExp ${ }_{R e g}^{E L}$ & $\begin{array}{l}\text { Backward spillover stemming from the export experience in New EU members of manufacturing customers that are located in the same region of } \\
\text { the BS firm }\end{array}$ \\
\hline BackExp ${ }_{R e g}^{N E}$ & $\begin{array}{l}\text { Backward spillover stemming from the export experience in extra-European countries of manufacturing customers that are located in the same } \\
\text { region of the BS firm }\end{array}$ \\
\hline BackExp $_{\mathrm{Reg}}^{\mathrm{NEH}}$ & $\begin{array}{l}\text { Backward spillover stemming from the export experience in high income extra-European countries of manufacturing customers that are located in } \\
\text { the same region of the BS firm }\end{array}$ \\
\hline BackExp Reg $^{N E L}$ & $\begin{array}{l}\text { Backward spillover stemming from the export experience in low income extra-European countries of manufacturing customers that are located in } \\
\text { the same region of the BS firm }\end{array}$ \\
\hline BackExp OthReg & Backward spillover from the export experience in European countries of manufacturing customers that are located in other regions \\
\hline BackExp EthReg & Backward spillover from the export experience in EU15 countries of manufacturing customers that are located in other regions \\
\hline BackExp OthReg & Backward spillover from the export experience in new EU members of manufacturing customers that are located in other regions \\
\hline BackExp OthReg & Backward spillover from the export experience in extra-European countries of manufacturing customers that are located in other regions \\
\hline BackExp OthReg & $\begin{array}{l}\text { Backward spillover from the export experience in high income extra-European countries of manufacturing customers that are located in other } \\
\text { regions }\end{array}$ \\
\hline BackExp OthReg & $\begin{array}{l}\text { Backward spillover from the export experience in low income extra-European countries of manufacturing customers that are located in other } \\
\text { regions }\end{array}$ \\
\hline
\end{tabular}

Controls

$L P$

Age, Age $e^{2}$

$L a b, L a b^{2}$

FDIOFF
Logarithm of labour productivity (value added over number of workers)

Age of the firm and its squared value

Number of workers and its squared value

FDI or Offshorer dummy 
Table A1 (Continued)

\begin{tabular}{|c|c|}
\hline Variable & Description \\
\hline Group & Dummy for belonging to a group \\
\hline Sale $_{\text {nat }}$, Sale $_{\text {nat }}{ }^{2}$ & National sales over total turnover and its squared value \\
\hline Sell Large $_{\text {L }}$ & Dummy for seller to large manufacturing firms \\
\hline Sell $_{\text {SMES }}$ & Dummy for seller to small and medium manufacturing firms \\
\hline Inno $_{\text {Serv }}$ & Service innovation dummy \\
\hline Inno $_{\text {Proc }}$ & Process innovation dummy \\
\hline$L P_{\text {Reg }}$ & Regional manufacturing labour productivity \\
\hline ForOwn & Dummy for foreign-owned firms \\
\hline BackN & Thickness spillover \\
\hline$G D P_{\text {Reg }}$ & Regional GDP \\
\hline $\operatorname{ExpOp}_{\text {Reg }}$ & Regional export openness \\
\hline
\end{tabular}

Table A2

Descriptive statistics by export destination.

\begin{tabular}{|c|c|c|c|c|c|c|c|c|}
\hline Variable & NonExporter & Exporter & Exporter $^{E}$ & Exporter $^{E H}$ & Exporter $^{E L}$ & Exporter $^{N E}$ & Exporter $^{N E H}$ & Exporter $^{N E L}$ \\
\hline$L P$ & 3.64 & 3.76 & 3.78 & 3.74 & 3.59 & 3.85 & 3.87 & 3.78 \\
\hline Age & 15.96 & 16.85 & 17.04 & 16.69 & 12.36 & 17.17 & 16.46 & 19.19 \\
\hline$L a b$ & 3.17 & 3.10 & 3.09 & 3.10 & 3.12 & 3.08 & 3.10 & 3.00 \\
\hline FDIOFF & 0.03 & 0.14 & 0.11 & 0.10 & 0.19 & 0.21 & 0.20 & 0.27 \\
\hline Group & 0.26 & 0.26 & 0.28 & 0.29 & 0.19 & 0.25 & 0.27 & 0.08 \\
\hline Sale $_{\text {nat }}$ & 42.96 & 54.31 & 54.26 & 53.30 & 48.04 & 50.51 & 48.30 & 44.85 \\
\hline Sell Large & 0.46 & 0.69 & 0.67 & 0.70 & 0.81 & 0.76 & 0.80 & 0.73 \\
\hline Sell $_{S M E S}$ & 0.58 & 0.60 & 0.63 & 0.65 & 0.65 & 0.53 & 0.53 & 0.58 \\
\hline Inno $_{\text {Serv }}$ & 0.38 & 0.43 & 0.43 & 0.39 & 0.58 & 0.47 & 0.43 & 0.50 \\
\hline Inno $_{\text {Proc }}$ & 0.27 & 0.31 & 0.31 & 0.32 & 0.27 & 0.35 & 0.35 & 0.31 \\
\hline
\end{tabular}

Table A3

Destination-specific backward spillovers from export: robustness.

\begin{tabular}{|c|c|c|c|c|c|c|c|c|c|c|}
\hline & \multicolumn{2}{|c|}{ Foreign ownership } & \multicolumn{2}{|l|}{ Thickness } & \multicolumn{2}{|c|}{ Regional GDP } & \multicolumn{2}{|c|}{ Regional export } & \multicolumn{2}{|c|}{2 years lagged spillovers } \\
\hline & Exporter $^{N E}$ & Exporter $^{N E H}$ & Exporter $^{N E}$ & Exporter $^{N E H}$ & Exporter $^{N E}$ & Exporter $^{N E H}$ & Exporter $^{N E}$ & Exporter $^{N E H}$ & Exporter $^{N E}$ & Exporter $^{N E H}$ \\
\hline \multicolumn{11}{|l|}{ Controls } \\
\hline \multirow[t]{2}{*}{$L P$} & $0.146^{*}$ & $0.162^{*}$ & $0.163^{*}$ & $0.185^{* *}$ & $0.162^{*}$ & $0.184^{*}$ & $0.167^{*}$ & $0.185^{*}$ & $0.168^{*}$ & $0.183^{*}$ \\
\hline & [0.088] & {$[0.090]$} & [0.092] & [0.094] & [0.092] & [0.094] & {$[0.092]$} & [0.095] & [0.091] & [0.095] \\
\hline \multirow[t]{2}{*}{ age } & 0.001 & -0.009 & -0.002 & -0.012 & -0.002 & -0.012 & -0.002 & -0.012 & -0.003 & -0.012 \\
\hline & {$[0.009]$} & {$[0.007]$} & [0.009] & {$[0.008]$} & [0.009] & [0.008] & [0.009] & {$[0.008]$} & [0.009] & {$[0.008]$} \\
\hline \multirow[t]{2}{*}{$a g e^{2}$} & 0 & 0 & 0 & $0.000^{*}$ & 0 & $0.000^{*}$ & 0 & $0.000^{*}$ & 0 & $0.000^{*}$ \\
\hline & {$[0.000]$} & {$[0.000]$} & {$[0.000]$} & {$[0.000]$} & {$[0.000]$} & [0.000] & {$[0.000]$} & {$[0.000]$} & {$[0.000]$} & {$[0.000]$} \\
\hline \multirow[t]{2}{*}{$L a b$} & 0.12 & 0.067 & 0.134 & 0.078 & 0.132 & 0.077 & 0.121 & 0.064 & 0.121 & 0.052 \\
\hline & [0.319] & [0.346] & [0.323] & [0.352] & [0.323] & [0.351] & [0.317] & [0.347] & [0.318] & {$[0.346]$} \\
\hline \multirow[t]{2}{*}{$L a b^{2}$} & -0.02 & -0.008 & -0.021 & -0.009 & -0.021 & -0.009 & -0.021 & -0.008 & -0.021 & -0.006 \\
\hline & [0.039] & {$[0.042]$} & [0.039] & [0.042] & [0.039] & [0.042] & [0.038] & {$[0.042]$} & [0.039] & {$[0.042]$} \\
\hline \multirow[t]{2}{*}{ FDIOFF } & $0.823^{* * *}$ & $0.787^{* * * *}$ & $0.869^{* * *}$ & $0.825^{* * *}$ & $0.866^{* * * *}$ & $0.823^{* * * *}$ & $0.884^{* * * *}$ & $0.859^{* * * *}$ & $0.876^{* * *}$ & $0.840^{* * * *}$ \\
\hline & {$[0.272]$} & [0.305] & [0.247] & {$[0.265]$} & [0.247] & [0.265] & [0.250] & {$[0.271]$} & [0.247] & {$[0.271]$} \\
\hline \multirow[t]{2}{*}{ Group } & -0.168 & -0.14 & -0.092 & -0.064 & -0.093 & -0.063 & -0.087 & -0.05 & -0.089 & -0.053 \\
\hline & [0.184] & [0.181] & [0.162] & [0.157] & [0.163] & [0.157] & {$[0.160]$} & [0.154] & {$[0.160]$} & {$[0.154]$} \\
\hline \multirow[t]{2}{*}{ Sale $_{\text {nat }}$} & $0.048^{* * *}$ & $0.041^{* * *}$ & $0.047^{* * * *}$ & $0.040^{* * * * *}$ & $0.047^{* * * *}$ & $0.040^{* * * *}$ & $0.046^{* * * *}$ & $0.039^{* * * *}$ & $0.046^{* * * *}$ & $0.039^{* * * *}$ \\
\hline & {$[0.008]$} & [0.009] & [0.008] & [0.009] & [0.008] & [0.009] & [0.008] & [0.009] & {$[0.008]$} & [0.009] \\
\hline \multirow[t]{2}{*}{ Sale $_{\text {nat }}^{2}$} & $-0.000^{* * *}$ & $-0.000^{* * *}$ & $-0.000^{* * *}$ & $-0.000^{* * *}$ & $-0.000^{* * * *}$ & $-0.000^{* * *}$ & $-0.000^{* * *}$ & $-0.000^{* * *}$ & $-0.000^{* * *}$ & $-0.000^{* * *}$ \\
\hline & {$[0.000]$} & {$[0.000]$} & {$[0.000]$} & {$[0.000]$} & {$[0.000]$} & {$[0.000]$} & {$[0.000]$} & {$[0.000]$} & {$[0.000]$} & {$[0.000]$} \\
\hline \multirow[t]{2}{*}{ Sell $_{\text {Large }}$} & $0.625^{* * *}$ & $0.715^{* * *}$ & $0.631^{* * *}$ & $0.725^{* * *}$ & $0.634^{* * * *}$ & $0.726^{* * * *}$ & $0.630^{* * *}$ & $0.717^{*+*+}$ & $0.633^{* * *}$ & $0.727^{* * *}$ \\
\hline & [0.226] & [0.239] & [0.216] & [0.225] & [0.216] & [0.225] & [0.217] & [0.225] & {$[0.216]$} & {$[0.226]$} \\
\hline \multirow[t]{2}{*}{ Sell $_{S M E S}$} & $-0.359^{* * *}$ & $-0.327^{* * *}$ & $-0.369^{* * *}$ & $-0.342^{* * * *}$ & $-0.369^{* * *}$ & $-0.344^{* * *}$ & $-0.370^{* * * *}$ & $-0.345^{* * *}$ & $-0.374^{* * *}$ & $-0.339^{* * *}$ \\
\hline & [0.119] & [0.122] & [0.119] & [0.119] & [0.119] & [0.119] & {$[0.116]$} & [0.117] & {$[0.116]$} & {$[0.118]$} \\
\hline \multirow[t]{2}{*}{ Inno $_{\text {serv }}$} & -0.058 & -0.114 & -0.091 & -0.158 & -0.092 & -0.157 & -0.089 & -0.154 & -0.091 & -0.163 \\
\hline & [0.140] & [0.164] & [0.126] & [0.154] & [0.126] & [0.154] & [0.124] & [0.154] & [0.125] & [0.154] \\
\hline \multirow[t]{2}{*}{ Inno $_{\text {proc }}$} & 0.184 & 0.168 & 0.172 & 0.161 & 0.173 & 0.162 & 0.187 & 0.176 & 0.193 & 0.18 \\
\hline & [0.190] & [0.204] & [0.194] & [0.208] & [0.193] & [0.207] & [0.194] & [0.206] & [0.193] & [0.206] \\
\hline \multirow[t]{2}{*}{$L P_{R e g}$} & $1.574^{* *}$ & -0.647 & 1.232 & -0.636 & 0.571 & -1.165 & $1.621^{*}$ & -0.758 & $1.643^{* *}$ & -0.109 \\
\hline & {$[0.760]$} & [1.012] & [0.856] & [1.145] & [1.018] & [1.316] & [0.839] & [1.169] & {$[0.780]$} & [1.007] \\
\hline \multirow[t]{2}{*}{ ForOwn } & $0.541^{* * *}$ & $0.627^{* * i}$ & & & & & & & & \\
\hline & [0.261] & [0.273] & & & & & & & & \\
\hline BackN & & & $\begin{array}{l}0.166 \\
{[0.129]}\end{array}$ & $\begin{array}{l}0.16 \\
{[0.166]}\end{array}$ & & & & & & \\
\hline$G D P_{R e g}$ & & & & & $\begin{array}{l}0.247 \\
{[0.154]}\end{array}$ & $\begin{array}{l}0.209 \\
{[0.203]}\end{array}$ & & & & \\
\hline ExpOp $_{\text {Reg }}$ & & & & & & & $\begin{array}{l}-0.279 \\
{[0.588]}\end{array}$ & $\begin{array}{l}-0.486 \\
{[0.743]}\end{array}$ & & \\
\hline
\end{tabular}


Table A3 (Continued)

\begin{tabular}{|c|c|c|c|c|c|c|c|c|c|c|}
\hline & \multicolumn{2}{|c|}{ Foreign ownership } & \multicolumn{2}{|l|}{ Thickness } & \multicolumn{2}{|c|}{ Regional GDP } & \multicolumn{2}{|c|}{ Regional export } & \multicolumn{2}{|c|}{2 years lagged spillovers } \\
\hline & Exporter $^{N E}$ & Exporter $^{N E H}$ & Exporter $^{N E}$ & Exporter $^{N E H}$ & Exporter $^{N E}$ & Exporter $^{N E H}$ & Exporter $^{N E}$ & Exporter $^{N E H}$ & Exporter $^{N E}$ & Exporter $^{N E H}$ \\
\hline \multicolumn{11}{|c|}{ Independent variables } \\
\hline \multirow{2}{*}{ BackExp ${ }_{R e g}$} & $0.119^{* * *}$ & & 0.072 & & 0.07 & & $0.140^{*}$ & & $0.102^{* *}$ & \\
\hline & {$[0.056]$} & & [0.073] & & {$[0.071]$} & & [0.079] & & {$[0.050]$} & \\
\hline \multirow[t]{2}{*}{ BackExp OthReg } & 0.035 & & -0.065 & & -0.06 & & 0.003 & & 0.007 & \\
\hline & {$[0.142]$} & & [0.137] & & {$[0.131]$} & & {$[0.132]$} & & {$[0.116]$} & \\
\hline \multirow[t]{2}{*}{ BackExp $p_{R e g}^{N E H}$} & & $0.560^{* * * *}$ & & $0.452^{* *}$ & & $0.460^{* *}$ & & $0.631^{* * *}$ & & $0.478^{* * *}$ \\
\hline & & {$[0.200]$} & & {$[0.206]$} & & {$[0.214]$} & & [0.199] & & [0.167] \\
\hline \multirow[t]{2}{*}{ BackExp OthReg } & & $0.911^{* * *}$ & & $0.609^{*}$ & & $0.719^{*}$ & & $0.834^{*}$ & & 0.482 \\
\hline & & [0.448] & & {$[0.370]$} & & [0.406] & & {$[0.446]$} & & [0.323] \\
\hline Observations & 806 & 806 & 846 & 846 & 846 & 846 & 846 & 846 & 846 & 846 \\
\hline Pseudo- $R^{2}$ & 0.239 & 0.263 & 0.24 & 0.261 & 0.24 & 0.261 & 0.238 & 0.26 & 0.238 & 0.26 \\
\hline Wald $\mathrm{Chi}^{2}$ & 363.8 & 642.5 & 481.5 & 925.9 & 491 & 874 & 480.9 & 1025 & 427.5 & 1040 \\
\hline Log-likelihood & -181 & -153.6 & -185.4 & -158.2 & -185.2 & -158.2 & -185.8 & -158.4 & -185.8 & -158.4 \\
\hline
\end{tabular}

Robust standard errors in brackets are clustered by region-sector pair. Area and 2-digit sector dummies are included in every regressions. E: exports to European Countries: $N E$ : exports to extra-European countries; NEH: exports to high income extra-European countries.

The drop in the number of observations with respect to the full sample is because some sector and area dummies perfectly predict the export status.

${ }_{* * *}^{*} p<.10$.

*** $p<.05$.

$p<.01$.

\section{References}

Andersen, P. H., \& Strandskov, J. (1997). International market selection. A cognitive mapping perspective. Journal of Global Marketing, 11(3), 65-84.

Andersen, O., \& Buvik, A. (2002). Firms' internationalization and alternative approaches to the international customer/market selection. International Business Review, 11(3), 347-363.

Andersson, U., Blankenburg Holm, D., \& Johanson, M. (2005). Opportunities relational embeddedness and network structure. In A. Hadjikhani, P. Ghauri, J. amp, \& Johanson (Eds.), Managing opportunity development in business networks (pp. 27 48). New York: Palgrave Macmillan.

Arkolakis, C. (2010). Market penetration costs and the new consumers margin in international trade. Journal of Political Economy, 118(6), 1151-1199.

Axelsson, B., \& Johanson, J. (1992). Foreign market entry. The Textbook vs, the Network view. In B. Axelsson, G. amp, \& Easton (Eds.), Industrial networks. A new view of reality (pp. 218-234). London: Routledge.

Ball, D. A., Lindsay, V. J., \& Rose, E. L. (2008). Rethinking the paradigm of service internationalisation: Less resource-intensive market entry modes for informationintensive soft services. Management International Review, 48, 413-431.

Balabanis. (2000). Factors affecting Export Intermediaries' Service Offerings: The British example. Journal of International Business Studies, 31(1), 83-99.

Bernard, A. B., \& Jensen, B. J. (2004). Why some firms export. The Review of Economics and Statistics, 86(2), 561-569.

Bell, J. (1995). The internationalisation of small computer software firms. A further challenge to "stage" theories. European Journal of Marketing, 29(8), 60-75.

Blomstermo, A., \& Sharma, D. D. (2003). Learning in the internationalization process of firm. Cheltenham, UK: Edward Elger.

Boggs, J. S., \& Rantisi, N. M. (2003). The "relational turn" in economic geography. Journal of Economic Geography, 3, 109-116.

Bottazzi, L., \& Peri, G. (2003). Innovation and spillovers in regions: Evidence from European patent data. European Economic Review, 47, 687-710.

Brewer, P. A. (2007). Operationalizing psychic distance: A revised approach. Journal of International Marketing, 15(1), 44-66.

Buckley, P., Pass, C. L., \& Prescott, K. (1999). The internationalization of service firms: A comparison with the manufacturing sector. In P. Buckley \& P. Ghauri (Eds.), The internationalization of the firm: A reader (pp. 149-164). London: Thomson.

Chetty, S., \& Patterson, A. (2002). Developing internationalization capability through industry groups: The experience of a telecommunications joint action group. Journal of Strategic Marketing, 10(1), 69-89.

Clerides, S., Lach, S., \& Tybout, J. (1998). Is learning by exporting important? Microdynamic evidence from Colombia Mexico and Morocco. Quarterly Journal of Economics, 113(3), 903-948.

Combes, P. P., \& Overman, H. G. (2004). The spatial distribution of economic activity in European Union. In V. Henderson \& J. F. Thisse (Eds.), Handbook of regional and urban economics: City and geography (pp. 2845-2910). North Holland.

Coviello, N. E., \& Munro, H. J. (1995). Growing the entrepreneurial firm: Networking for international market development. European Journal of Marketing, 29(7) 361-386.

Coviello, N. E., \& Munro, H. J. (1997). Network relationships and the internationalisation process of small software firms. International Business Review, 6(4) 361-386.

Crescenzi, R., Rodriguez-Pose, A., \& Storper, M. (2012). The territorial dynamics of innovation in China and India. Journal of Economic Geography, 12(5), 1055-1085.

Crescenzi, R., \& Rodriguez-Pose, (2008). R\&D spillovers, innovation systems and the genesis of regional growth in Europe. Regional Studies, 42, 51-67.

Crinò, R., \& Epifani, P. (2012). Productivity, quality and export behaviour. The Economic Journal6(4) http://dx.doi.org/10.1111/j.1468-0297.2012.02529.x.
Damijan, J. P., Polanec, S., \& Prasnikar, J. (2004). Self-selection, export market heterogeneity and productivity improvements: Firm level evidence from Slovenia. LICOS Discussion Papers 14804, K.U.Leuven.

Disdier, A. C., \& Mayer, T. (2007). Je t'aime, moi nonplus: Bilateral opinions and international trade. European Journal of Political Economy, 23(4), 1140-1159.

Dow, D. S. (2000). A note on psychological distance and export market selection. Journal of International Marketing, 8(1), 51-64.

Easton, G., \& Araujo, L. (1992). Non-economic exchange in industrial networks. In B. Axelsson \& G. Easton (Eds.), Industrial networks. A new view of reality (pp. 62-84). London: Routledge.

European Commission. (2009). Challenges for EU support to innovation in services. Fostering new markets and jobs through innovation. Commission Staff Working Document.

Eickelpasch, A., \& Vogel, A. (2009). Determinants of export behaviour of German Business Services companies. Discussion Papers of DIW Berlin, 876

Ellis, P. D. (2008). Does psychic distance moderate the market size-entry sequence relationship? Journal of International Business Studies, 39(3), 351-369.

Ellis, P. D. (2007). Paths to foreign markets: Does distance to market affect firm internationalisation? International Business Review, 16, 573-593.

Erramilli, M. K., \& Rao, C. P. (1990). Choice of foreign market entry modes by service firms: Role of market knowledge. Management International Review, 30, 135-150.

Eurostat. (2005). Statistics in focus, science and technology, 4/2005. Luxembourg: R\&D Statistics.

Freeman, S., Giroud, A., Kalfadellis, P., \& Ghauri, P. (2012). Psychic distance and environment: Impact on increased resource commitment. European Business Review, 24(4), 351-373.

Furrer, O., Shaw-Chimg Liu, B., \& Sudharshan, D. (2000). The relationships between culture and service quality perceptions: Basis for cross-cultural market segmentation and resource allocation. Journal of Service Research, 2(4), 355-371.

Furrer, O., Shaw-Chimg Liu, B., \& Sudharshan, D. (2001). The relationships between culture and behavioral intentions towards services. Journal of Service Research, 2(4), $355-371$.

Giroud, A. (2012). Mind the gap: How linkages strengthen understanding of spillovers The European Journal of Development Research, 24(1), 20-25.

Greenaway, D., Sousa, N., \& Wakelin, K. (2004). Do domestic firms learn to export from multinationals? European Journal of Political Economy, 20, 1027-1043.

Gourlay, A., Seaton, J., \& Suppakitjarak, J. (2005). The determinants of export behaviour in UK service firms. The Service Industries Journal, 25(7), 879-889.

Guiso, L., Sapienza, P., \& Zingales, L. (2009). Cultural biases in economic exchange. Quarterly Journal of Economics, 124(3), 1095-1131.

Gullstrand, J. (2011). Firm and destination specific export costs: The case of the Swedish food sector. Food Policy, 36, 204-213.

Hatani, F. (2009). The logic of spillover interception: The impact of global supply chains in China. Journal of World Business, 44, 158-166.

Hadjikhani, A., Ghauri, P., \& Johanson, J. (2005). Introduction: Opportunity development in business networks. In A. Hadjikhani, P. Ghauri, \& J. Johanson (Eds.) Managing opportunity development in business networks (pp. 1-25). New York: Palgrave Macmillan.

Hausmann, R., Hwang, J., \& Rodrik, D. (2007). What you export matters. Journal of Economic Growth, 12(1), 1-25.

Head, K., Mayer, T., \& Ries, J. (2009). How remote is the offshoring threat? European Economic Review, 53(4), 429-444.

Hellman, P. (1996). The internationalisation of Finnish financial service companies. International Business Review, 5, 191-208.

Hitt, M. A., Bierman, L., Uhlenbruck, K., \& Shimizu, K. (2006). The importance of resources in the internationalization process of professional service firms: The good the bad and the ugly. Academy of Management Journal, 49(6), 1137-1157. 
Jaklič, Ćirjaković, A., \& Chidlow, A. (2012). Exploring the effects of international sourcing on manufacturing versus service firms. The Service Industries Journal, 32(7), 1193-1207.

Javalgi, R. G., Lawson, D., Gross, A. C., \& White, S. D. (1998). Firm characteristics and export propensity: A comparison of manufacturers and manufacturing based service providers. International Business Review, 7, 521-534.

Javorcik, B. S. (2004). Does foreign direct investment increase the productivity of domestic firms? In search of spillovers through backward linkages. American Economic Review, 4(3), 605-627.

Johanson, J., \& Mattsson, L. (1988). Internationalisation in industrial systems - A network approach. In N. Hood \& J. E. Vahlne (Eds.), Strategies in global competition (pp. 287-314). London: Croom Helm.

Johanson, J., \& Vahlne, J. E. (1977). The internationalisation process of the firm. A model of knowledge development and increasing foreign market commitment. Journal of International Business Studies, Spring/Summer, 8(1), 23-32.

Johanson, J., \& Wiedersheim-Paul, F. (1975). The internationalisation of the firm: Four Swedish case studies. Journal of Management Studies, 12(3), 305-322.

Koenig, P. (2009). Agglomeration and the export decisions of French firms. Journal of Urban Economics, 66(3), 186-195.

Koenig, P., Mayneris, F., \& Poncet, S. (2010). Local export spillovers in France. European Economic Review, 54, 622-641.

Krautheim, S. (2012). Heterogeneous firms, exporter networks and the effect of distance on international trade. Journal of International Economics, 87, 27-35.

Lawless, M. (2010). Geography and firm exports: New evidence on the nature of sunk costs. Review of World Economics, 146, 691-707.

Lazear, E. (1999). Culture and language. Journal of Political Economy, 107(6), S95-S126.

Leamer, E., \& Storper, M. (2001). The economic geography of the internet age. Journal of International Business Studies, 32(4), 641-665.

Lejour, A. M., \& Smith, P. M. (2008). International trade in services. Editorial introduction. Journal of Industry Competition and Trade, 8, 169-180.

Lindqvist, M. (1988). Internationalisation of small technology-based Finns: Three illustrative case studies on Swedish firms. Stockholm School of Economics Research Paper, 88/15.

Love, J. H., \& Mansury, M. A. (2009). Exporting and productivity in business services: Evidence from the United States. International Business Review, 18(6), 630-642.

Lucas, R. E. (1988). On the mechanics of economic development. Journal of Monetary Economics, 22(1), 3-42.

Majkgard, A., \& Sharma, D. D. (1998). Client-following and market-seeking strategies in the internationalisation of service firms. Journal of Business-to-Business Marketing, 4, 1-41.

Manning, S., Roza, M., Lewin, A., \& Volberda, H. (2009). Why distance matters: The dynamics of offshore location decisions. Duke Cyper Working Paper.

Martin, X., Swaminathan, A., \& Mitchell, W. (1998). Organizational evolution in the interorganizational environment: Incentives and constraints on international expansion strategy. Administrative Science Quarterly, 43(3), 566-601.

Melitz, M. J. (2003). The impact of trade on intra-industry reallocations and aggregate industry productivity, econometrica. Econometric Society, 71(6), 1695-1725, November.

Midelfart, K. H., Overman, H. G., \& Redding, S. (2004). The location of European industry. In A. Dierx, F. Ilzkovitz, \& K. Sekkart (Eds.), European integration and the functioning of product markets (pp. 113-170). Cheltenham: Edward Elgar.
Miozzo, M., \& Grimshaw, D. (2008). Service multinationals and forward linkages with client firms: The case of IT outsourcing in Argentina and Brazil. International Business Review, 17(1), 8-27.

Miozzo, M., Yamin, M., \& Ghauri, P. N. (2012). Strategy and structure of service multinationals and their impact on linkages with local firms. The Service Industries Journal, 32(7), 1171-1191.

Moulton, B. (1990). An illustration of a pitfall in estimating the effects of aggregate variables on micro unit. Review of Economics and Statistics, 72, 219-256.

Murray, J. Y., \& Kotabe, M. (1999). Sourcing strategies of US service companies: A modified transaction-cost analysis. Strategic Management Journal, 20(9), 791-809.

Nefussi, B. \& Schwellnus, C. (2010). Does FDI in manufacturing cause FDI in business services? Evidence from French firm-level data. Canadian Journal of Economics, 43(1), 180-203.

Pahlberg, C., \& Thilenius, P. (2005). Opportunity development for ongoing business relationships. In A. Hadjikhani, P. Ghauri, \& J. Johanson (Eds.), Managing opportunity development in business networks (pp. 250-268). New York: Palgrave Macmillan.

Parasuraman, A., Zeithaml, V. A., \& Berry, L. L. (1988). SERVQUAL: A multiple-item scale for measuring consumer perceptions of service quality. Journal of Retailing, 64(1), $12-40$.

Parasuraman, A., Zeithaml, V. A., \& Berry, L. L. (1994). Alternative scales for measuring service quality: A comparative assessment based on psychometric and diagnostic criteria. Journal of Retailing, 70(3), 201-230.

Pla-Barber, J., \& Ghauri, P. N. (2012). Internationalization of service industry firms: Understanding distinctive characteristics. The Service Industries Journal, 32(7), 1007-1010.

Pla-Barber, J., Sanchez-Peinado, E., \& Madhok, A. (2010). Investment and control decisions in foreign markets: Evidence from service industries. British Journal of Management, 21, 736-753.

Roberts, M., \& Tybout, J. R. (1997). The Decision to Export in Colombia: An empirical model of entry with sunk costs. American Economic Review, 87, $545-564$.

Rodriguez, A., \& Nieto, M. J. (2012). The internationalization of knowledge-intnsive business services: The effect of collaboration and the mediating role of innovation. The Service Industries Journal, 32(7), 1057-1075.

Sarathy, R. (1994). Global strategy in service industries. Long Range Planning, 27(6), $115-124$

Turnbull, P., Ford, D., \& Cunningham, M. (1996). Interaction relationships and networks in business markets: An evolving perspective. Journal of Business and Industrial Marketing, 11(34), 44-62.

UNCTAD. (2008). World investment report. Transnational corporations and the infrastructure challenge. Switzerland: UNCTAD.

UNCTAD. (2012). World investment report. Towards a new generation of investment policies. Switzerland: UNCTAD.

Villar, C., Pla-Barber, J., \& León-Darder, F. (2012). Service characteristics as moderators of the entry mode choice: Empirical evidence in the hotel industry. The Service Industries Journal, 32(7), 1137-1148.

Yilmaz, K., \& Taymaz, E. (2008). Foreign direct investment and productivity spillovers: Identifying linkages through product-based measures. Mimeo.

Zain, M., \& Ng, S. I. (2006). The impact of network relationships on SMEs' internationalization process. Thunderbird International Business Review, 48(2), 183-205. 